107 Royal Netherlands Institute for Sea Research

This is a postprint of:

Castañeda, I.S., Schouten, S., Paetzold, J., Lucassen, F., Kasemann, S., Kuhlmann, H. \& Schefuß, E. (2016).

Hydroclimate variability in the Nile River Basin during the past 28,000 years. Earth and Planetary Science Letters, 438, 47-56

Published version: $\underline{\mathrm{dx} . \text { doi.org/10.1016/j.epsl.2015.12.014 }}$

Link NIOZ Repository: $\underline{w w w . v l i z . b e / e n / i m i s ? m o d u l e=r e f \& r e f i d=254286}$

[Article begins on next page]

The NIOZ Repository gives free access to the digital collection of the work of the Royal Netherlands Institute for Sea Research. This archive is managed according to the principles of the Open Access Movement, and the Open Archive Initiative. Each publication should be cited to its original source - please use the reference as presented.

When using parts of, or whole publications in your own work, permission from the author(s) or copyright holder(s) is always needed. 


\section{Hydroclimate variability in the Nile River Basin during the}

\section{Abstract}

14 It has long been known that extreme changes in North African hydroclimate occurred

15 during the late Pleistocene yet many discrepancies exist between sites regarding the timing,

16 duration and abruptness of events such as Heinrich Stadial (HS) 1 and the African Humid

17 Period (AHP). The hydroclimate history of the Nile River is of particular interest due to its

18 lengthy human occupation history yet there are presently few continuous archives from the

19 Nile River corridor, and pre-Holocene studies are rare. Here we present new organic and

20 inorganic geochemical records of Nile Basin hydroclimate from an eastern Mediterranean

21 (EM) Sea sediment core spanning the past $28 \mathrm{ka} \mathrm{BP}$. Our multi-proxy records reflect the

22 fluctuating inputs of Blue Nile versus White Nile material to the EM Sea in response to 
23 gradual changes in local insolation and also capture abrupt hydroclimate events driven by

24 remote climate forcings, such as HS1. We find strong evidence for extreme aridity within

25 the Nile Basin evolving in two distinct phases during HS1, from 17.5 to $16 \mathrm{ka}$ BP and from

26 16-14.5 ka BP, whereas peak wet conditions during the AHP are observed from 9-7 ka BP.

27 We find that zonal movements of the Congo Air Boundary (CAB), and associated shifts in

28 the dominant moisture source (Atlantic versus Indian Ocean moisture) to the Nile Basin,

29 likely contributed to abrupt hydroclimate variability in northern East Africa during HS1

30 and the AHP as well as to non-linear behavior of hydroclimate proxies. We note that

31 different proxies show variable gradual and abrupt responses to individual hydroclimate

32 events, and thus might have different inherent sensitivities, which may be a factor partially

33 contributing to the controversy surrounding the abruptness of past events such as the AHP.

34 During the Late Pleistocene the Nile Basin experienced extreme hydroclimate fluctuations,

35 which presumably impacted Paleolithic cultures residing along the Nile corridor.

37 Keywords: African Humid Period, hydroclimate, Nile River, Heinrich Stadial, leaf wax,

38 deuterium isotopes

40 1. Introduction

41 The paleoclimate history of the Nile River valley in East Africa is of interest due to its

42 rich history of human occupation (Vermeersch and Van Neer, 2015). Relationships

43 between climate and the distribution of settlements on the Nile River corridor have long

44 been recognized and it is hypothesized that extreme changes in African hydroclimate

45 helped shape the growth and led to the decline of numerous complex societies [Kuper and 
46 Kröpelin, 2006]. One of the most dramatic changes in North African hydroclimate, the so-

47 called African Humid Period (AHP) [deMenocal et al., 2000], occurred during the early

48 Holocene when increased rainfall allowed vegetation, lakes and human populations to

49 occupy a "green Sahara", a region that today is a hyperarid desert [Kuper and Kröpelin,

50 2006]. Variability in Nile River flow also played an important role in shaping Egypt's

51 civilizations with the collapse of the Old Kingdom at 4,160 years before present, attributed

52 to a 30 year absence of annual Nile flooding [Stanley et al., 2003]. Although lacking direct

53 evidence, it is hypothesized that HS1, which is recognized as an extreme and widespread

54 drought in North Africa, also had a major impact on Paleolithic cultures [Stager et al., $552011]$

56 Previous investigations of North African hydroclimate since the Last Glacial Maximum

57 (LGM) have documented abrupt and extreme hydrological fluctuations as well as

58 considerable temporal and spatial heterogeneity. The timing and duration of the AHP varies

59 with latitude [e.g. Kuper and Kröpelin, 2006] with sites in the north experiencing a shorter

60 humid phase and earlier termination than sites in the south [Shanahan et al., 2015],

61 following changes in northern hemisphere summer insolation. However, whether the

62 transitions leading into and out of the AHP were abrupt, gradual or stepwise (Fig. 1)

63 remains a highly debated issue [e.g. Kuper and Kröpelin, 2006; Costa et al., 2014;

64 deMenocal et al., 2000; Kuhlmann et al., 2004; Schefuß et al., 2005; Tierney and

65 deMenocal, 2013; Tierney et al., 2008; McGee et al., 2013; Junginger et al., 2014; Weldeab

66 et al., 2014; Marshall et al., 2011; Kutzbach and Street-Perrott, 1985; Claussen et al.,

67 1999]. In East Africa, the role of non-linear biogeophysical climate feedbacks is also

68 debated with recent studies concluding that non-linear biogeophysical climate feedbacks 
69 between precipitation and vegetation are absent [Weldeab et al., 2014], that a nonlinear

70 convection feedback associated with Indian Ocean SST could be an important contributor

71 to rainfall variability [Tierney and deMenocal, 2013], or that a non-linear change in

72 vegetation and sediment erosion occurred in the Early Holocene without a significant

73 decrease in precipitation [Blanchet et al., 2014].

74 Presently, a gap in our understanding of North African hydroclimate stems from a lack

75 of continuous archives in the vast Nile River corridor [Bard, 2013], which spans 35 degrees

76 of latitude $\left(4^{\circ} \mathrm{S}\right.$ to $\left.31^{\circ} \mathrm{N}\right)$ over its ca. $6670 \mathrm{~km}$ course and has a catchment of nearly 3 million

$77 \mathrm{~km}^{2}$. Here, we investigate the spatially integrated temperature and hydroclimate history of

78 the Nile River Basin by examining the geochemistry of a sediment core collected from the

79 Eastern Mediterranean (EM) Sea that receives sediment from the Nile River. We measured

80 multiple organic and inorganic geochemical parameters on the same samples to provide a

81 robust assessment of past hydroclimate variability and to examine shifts in the dominant

82 sources of material transported by the Nile River to the EM Sea. We focus the discussion

83 on two extreme and contrasting hydroclimate events: Heinrich Stadial (HS) 1, an arid

84 interval driven by an abrupt external forcing, and the AHP, a wet period driven by gradual

85 changes in insolation. We note that the term abrupt is used qualitatively in many

86 paleoclimate studies; for the purpose of this study we consider an event as abrupt if its

87 onset or termination occurs in 1,000 years or less.

88

89 2. Study Location

90 Sediment core GeoB7702-3 was collected from the continental slope offshore Israel

$91\left(31^{\circ} 39.1^{\prime} \mathrm{N}, 34^{\circ} 04.4^{\prime} \mathrm{E}, 562 \mathrm{~m}\right.$ water depth) during R/V Meteor cruise M52/2 in 2002 (Fig. 
92 2) [Pätzold et al., 2003]. The chronology of this $592 \mathrm{~cm}$ long core, which spans the past

9328,000 years before present (hereafter $28 \mathrm{ka} \mathrm{BP}$ ), is based on $15 \mathrm{AMS}{ }^{14} \mathrm{C}$ dates on

94 foraminifera and was previously published along with alkenone and TEX 86 sea surface

95 temperature (SST) estimates [Castañeda et al., 2010]. The surface currents flow in an

96 anticlockwise direction around the basin and sediment from the Nile River is transported

97 eastward to the coring site [Weldeab et al., 2002].

98 Precipitation over the Nile Basin derives from both Atlantic and Indian Ocean sources

99 [Gimeno et al., 2010]. Total annual precipitation within the Nile Basin fluctuates widely

100 (Fig. 2) related to the varying geographical influence of the Intertropical Convergence Zone

101 (ITCZ), marking the convergence of the northeast and southwest trade winds, and the

102 Congo Air Boundary (CAB), separating Atlantic and Indian Ocean sourced moisture

103 [Camberlin, 2009] (Fig. 1). In boreal summer when the ITCZ is at its northernmost

104 position, the $\mathrm{CAB}$ is at its most northerly and easterly extent, drawing Atlantic moisture to

105 East Africa. Conversely, when the ITCZ is at its southernmost position in boreal winter,

106 the $\mathrm{CAB}$ is located further to the south and does not extend as far eastward, restricting the

107 flow of Atlantic moisture across the continent [Camberlin, 2009]. From north to south

108 within the Nile Basin, the length of the rainy season increases as does the total rainfall

109 amount [Camberlin, 2009] (Fig. 2c).

110

111 3. Methods

112 3.1. Organic geochemical analyses

113 Core GeoB7702-3 was sampled at $5 \mathrm{~cm}$ intervals (average time step of 209 years) for

114 organic geochemical analyses using the methods detailed by Castañeda et al. [2010]. 
115 Freeze dried sediment samples were extracted with 9:1 dichloromethane (DCM)/methanol

116 (v/v) using an Accelerated Solvent Extractor (ASE 200). Alumina oxide column

117 chromatography was used to separate apolar, ketone and polar fractions with solvent

118 mixtures of 9:1 hexane/DCM (v/v), 1:1 hexane/DCM (v/v), and 1:1 DCM/methanol (v/v),

119 respectively. The apolar fractions were separated into saturated and unsaturated

120 hydrocarbon fractions using $\mathrm{AgNO}_{3}$-impregnated silica gel. The saturated fractions were

121 analyzed at MARUM, University of Bremen. A Thermo Trace gas chromatograph (GC)

122 coupled via a combustion reactor to a MAT252 mass spectrometer (MS) was used to

123 measure the carbon isotopic composition $\left(\delta^{13} \mathrm{C}\right)$ of $n$-alkanes while a Thermo Trace GC

124 coupled to a MAT253 MS was used to determine their deterium $(\delta \mathrm{D})$ isotopic composition.

125 Isotope values were measured against calibrated reference gas using $\mathrm{H}_{2}$ for $\delta \mathrm{D}$ and $\mathrm{CO}_{2}$ for

$126 \delta^{13} \mathrm{C} . \delta \mathrm{D}$ and $\delta^{13} \mathrm{C}$ values are reported in \%o versus VSMOW and VPDB, respectively. The

127 performance of the systems was checked every sixth analyses by measurement of an $n$ -

128 alkane standard containing 16 compounds ranging from $-33 \%$ to $-261 \%$ VSMOW.

129 Measurements were only conducted when average absolute deviations against offline

130 values were $<0.3 \%$ and $<3 \%$ for $\delta^{13} \mathrm{C}$ and $\delta \mathrm{D}$, respectively. The $\mathrm{H}_{3}{ }^{+}$-factor was monitored

131 daily and was constant at $5.34 \pm 0.03 \%$ o $(n=28)$ for the measuring time. Further information

132 is provided by Schefu $\beta$ et al. [2011]. We measured $\delta^{13} \mathrm{C}$ and $\delta \mathrm{D}$ on the $\mathrm{C}_{31} n$-alkane, the

133 most abundant homologue. Reproducibility (the standard deviations of multiple analyses)

134 varied between $0 \%$ and $0.5 \%$ (average $0.1 \%$ ) for $\delta^{13} \mathrm{C}$, and $0 \%$ and $4 \%$ (average $1 \%$ ) for

$135 \delta \mathrm{D}$. Leaf wax $\delta \mathrm{D}$ values were corrected for global ice volume changes using the method 136 described by Wang et al. [2013]. 
137 Glycerol dialkyl glycerol tetraethers (GDGTs) were analyzed at NIOZ Royal

138 Netherlands Institute for Sea Research using the methods described by Castañeda et al.

139 [2010]. We previously examined EM SST using TEX86 [Castañeda et al., 2010]. Here the

140 newer BAYSPAR calibration [Tierney and Tingley, 2014] is applied to the TEX 86 record.

141 The deep water (>1000 m) Mediterranean Sea TEX 86 calibration of Kim et al. [2015] yields

142 approximately $4^{\circ} \mathrm{C}$ lower temperatures throughout the Holocene but overall trends remain

143 the same. We additionally analyzed branched GDGTs to examine the MBT' and CBT

144 indices [Weijers et al., 2007; Peterse et al., 2012], proxies for mean annual air temperature

145 (MAAT) and soil $\mathrm{pH}$.

146

147 3.2. Radiogenic Isotopes

148 Strontium (Sr) and neodymium (Nd) isotope ratios of bulk sediment samples were

149 analyzed by thermal ionization mass spectrometry (TIMS) on a Thermo Scientific Triton

150 Plus instrument at the Isotope Geochemistry Laboratory at MARUM. Homogenized

151 sediment powders were washed in $18.2 \mathrm{~m} \Omega$ water and approximately $100 \mathrm{mg}$ were

152 dissolved in a 5:1 mixture of triple distilled $\mathrm{HF}$ and $\mathrm{HNO}_{3}$, dried, and re-dissolved in 10001

153 of 2 molar $\mathrm{HNO}_{3}$ for chemical separation.

154 Sr was isolated from the matrix elements using miniaturized columns with $70 \mathrm{~L} \mathrm{Sr}$.Spec

155 resin (Eichrom Technologies, LLC, USA) following a separation procedure adapted from

156 Deniel and Pin [2001]. Rare earth elements (REE) were isolated as group from the run-off

157 of the Sr separation by TRU.Spec resin followed by the isolation of Nd from Sm by

158 LN.Spec resin. The setup of the REE and Nd separation columns and separation scheme

159 was adapted from Pin et al. [1994] and Mikova and Denkova [2007]. Total procedure 
160 blanks of $\mathrm{Sr}$ and Nd were below $140 \mathrm{pg}$ and $80 \mathrm{pg}$, respectively, insignificant with respect

161 to the amount of sample material used for analyses.

162 Sr was loaded with Ta-oxide emitter on Re single filaments and $\mathrm{Nd}$ with $0.1 \mathrm{~m}$

163 phosphoric acid on a Re double filament configuration and analyzed by TIMS in static

164 multi-collection mode. Instrumental mass-fractionation of $\mathrm{Sr}$ and $\mathrm{Nd}$ isotope ratios was

165 normalized to ${ }^{87} \mathrm{Sr} /{ }^{86} \mathrm{Sr}$ of 0.1194 and ${ }^{143} \mathrm{Nd} /{ }^{144} \mathrm{Nd}$ of 0.7219 , respectively. The external

166 long-term reproducibility according to the NIST 987 standard material is ${ }^{87} \mathrm{Sr} /{ }^{86} \mathrm{Sr}$

$1670.710256 \pm 16$ (2SD, n=33; period: January 2013 to April 2014), according to Nd standard

168 material JNdi-1 ${ }^{143} \mathrm{Nd} /{ }^{144} \mathrm{Nd}$ is $0.512104 \pm 14$ (2SD, $\mathrm{n}=23$; period: December 2011 to June 169 2014).

170

171 3.3. XRF core scanning

172 Element intensities were collected every $1 \mathrm{~cm}$ over a $12 \mathrm{~mm}^{2}$ area with down-core slit 173 size of $10 \mathrm{~mm}$ using generator settings of $10 \mathrm{kV}$, a current of $200 \mathrm{~mA}$, and a sampling time 174 of 30 seconds directly at the split core surface of the archive half with XRF Core Scanner

175 II (AVAATECH Serial No. 2) at the MARUM. The split core surface was covered with a

$1763 \mathrm{~m}$ thin SPEXCerti Prep Ultralene 1 foil. The data reported here were acquired by an

177 Amptek XR-100CR detector, the Amptek Digital Spectrum Analyzer PX2T/CR Power

178 Supply/Shaper and Amplifier, and an Oxford Instruments XTF5011 X-Ray Tube 93057

179 with rhodium (Rh) target material. Raw data spectra were processed by the analysis of X-

180 ray spectra by Iterative Least square software (WIN AXIL) package from Canberra 181 Eurisys. 


\subsection{Magnetic susceptibility (Multi-Sensor Core logger)}

184 Magnetic susceptibility (MS) was acquired non-destructively using a GEOTEK ${ }^{\mathrm{TM}}$ 185 (Surrey, UK) Multi-Sensor Core Logger (MSCL) at the MARUM. The measurements were 186 made in $1 \mathrm{~cm}$ steps over an area of $1 \mathrm{~cm}^{2}$ using the BARTINGTON ${ }^{\mathrm{TM}}$ point-sensor MS2F. 187 The resulting data is the volume specific MS in $\mathrm{e}^{-5} \mathrm{SI}$ units.

189 4. Results and Discussion

190 4.1. Sources of material to the coring site

191 Due to its large size, the presence of multiple vegetation zones and contrasting 192 environmental conditions within the Nile Basin, a first step to interpreting the GeoB7702-

1933 proxy records was to determine the main sources of terrestrial material to the core site.

194 The Nile River is comprised of two major tributaries, the White Nile and the Blue/Atbara

195 Nile, which drain contrasting geologic terranes and climate zones [Krom et al., 2002]. The

196 Blue Nile, sourced at Lake Tana, and the Atbara, drain catchments in the Ethiopian

197 Highlands largely consisting of Cenozoic volcanic rocks with low ${ }^{87} \mathrm{Sr} /{ }^{86} \mathrm{Sr}$ values $(0.7030$ 198 to 0.7048) and high $\varepsilon N d$ values [Krom et al., 2002; Box et al., 2011; Blanchet et al., 2013;

199 Blanchet et al., 2014]. In contrast, the White Nile is sourced at equatorial Lake Victoria 200 and the Precambrian crystalline basement rocks in its catchment are characterized by a 201 higher ${ }^{87} \mathrm{Sr} /{ }^{86} \mathrm{Sr}$ values (approximately 0.7105) and low $\varepsilon N d$ values [Krom et al., 2002; Box 202 et al., 2011; Blanchet et al., 2013; Blanchet et al., 2014]. Saharan dust is characterized by 203 high ${ }^{87} \mathrm{Sr} /{ }^{86} \mathrm{Sr}$ values of $>0.7173$ [Krom et al., 2002; Weldeab et al., 2002] while loess 204 sequences of the Negev desert (southern Israel; Fig. 2b) have ${ }^{87} \mathrm{Sr} /{ }^{86} \mathrm{Sr}$ values of 0.785 to 2050.7114 and $\varepsilon N d$ values of -11.6 to -4.6 [Ben Israel et al., 2015]. In GeoB7702-3, ${ }^{87} \mathrm{Sr} /{ }^{86} \mathrm{Sr}$ 
206 values range from 0.7080 to 0.7090 and thus likely represent a mixture of material derived

207 from the Blue Nile and White Nile (Fig. 3). These results are in good agreement with those

208 of nearby core 9509 (Fig. 2b) in the EM Sea [Box et al., 2011]. While some locations in

209 the EM Sea receive significant contributions of Saharan dust, the influence of eolian

210 material is minimal near the Nile Delta [Box et al., 2011]. A crossplot of ${ }^{87} \mathrm{Sr} /{ }^{86} \mathrm{Sr}$ ratios

211 and $\varepsilon N d$ can further differentiate sources of material from north and east Africa to the EM

212 Sea [Blanchet et al., 2013] and suggests that Saharan dust is not a significant contributor

213 to site GeoB7702-3 (Fig. 3a). We acknowledge that significant contributions of Saharan

214 dust to the core site in the past under different climate regimes cannot be fully ruled out.

215 We also note that loess sequences of the Negev have a similar radiogenic isotopic

216 composition to the White Nile [Ben Israel et al., 2015]. Negev loess derives from the Sinai-

217 Negev dune field, which in turn is sourced from the Nile Delta [Ben Israel et al., 2015;

218 Amit et al., 2011; Muhs et al., 2013]. This material can reach the EM Sea via the Wadi El

219 Arish and although this drainage is quite dry today it may have provided an additional

220 source of material during the AHP [Muhs et al., 2013].

221 The radiogenic isotope records, which we interpret as mainly reflecting Blue versus

222 White Nile sources, suggest increased input of Blue Nile material from 28 to $16 \mathrm{ka}$ BP

223 followed by a shift to increased input of White Nile material at 14 ka BP (Fig. 3b). A return

224 to increased Blue Nile input occurs at $12 \mathrm{ka} \mathrm{BP}$ (the Younger Dryas) and subsequently a

225 dramatic shift to increased contributions of White Nile material occurs, peaking in the early

226 Holocene (Fig. 3b). The mid to late Holocene is characterized by an overall shift to

227 increased inputs of Blue Nile material. These patterns have been previously documented

228 and are attributed to the role of Ethiopian Highland vegetation on Blue Nile sediment 
229 supply: during arid climate intervals limited vegetation cover in the Ethiopian Highlands

230 allowed for greater soil erosion during the summer monsoon rainy season whereas during

231 humid periods more extensive vegetation cover reduced erosion and led to relatively larger

232 inputs of White Nile material [Krom et al., 2002; Box et al., 2011].

234 4.2. Hydroclimate proxies

235 Long-chain $n$-alkanes form a major component of higher plant epicuticular leaf waxes 236 [Eglinton and Hamilton, 1967]. The carbon isotopic composition of plant leaf waxes 237 (hereafter $\delta^{13} \mathrm{C}_{w a x}$ ) can be used to distinguish between plants utilizing the $\mathrm{C}_{3}$ and $\mathrm{C}_{4}$ 238 photosynthetic pathways [e.g. Schefuß et al., 2003; Castañeda et al., 2009]. For the $\mathrm{C}_{31} n$ 239 alkane, $\mathrm{C}_{3}$ plants (most trees and cool-season grasses and sedges) are characterized by $240 \delta^{13} \mathrm{C}_{\text {wax }}$ values of around $-35.2 \%$ while $\mathrm{C}_{4}$ plants (warm-season grasses and sedges) are 241 more enriched in ${ }^{13} \mathrm{C}$ and have $\delta^{13} \mathrm{C}_{\text {wax }}$ values of around -21.7\%o [Castañeda et al., 2009].

242 Aridity is recognized as the dominant control on the large-scale distribution of $\mathrm{C}_{3}$ versus

$243 \mathrm{C}_{4}$ vegetation in tropical Africa [Schefuß et al., 2003; Castañeda et al., 2009]. The

244 deuterium isotopic composition of plant leaf waxes (hereafter $\delta \mathrm{D}_{w a x}$ ) provides information

245 on the isotopic composition of precipitation [e.g. Schefu $\beta$ et al., 2005]. $\delta \mathrm{D}_{\text {wax }}$ has been

246 interpreted to mainly reflect variability in precipitation amount in tropical Africa [e.g.

247 Schefuß et al., 2005; Tierney et al., 2008; Berke et al., 2012; Tierney and deMenocal, 2013;

248 Costa et al., 2014; Shanahan et al., 2015] (e.g. the "amount effect") although more

249 generally the isotopic composition of precipitation reflects the overall atmospheric

250 transport history of the airmass from which the moisture is derived (e.g. atmospheric

251 circulation) [Dansgaard, 1964; Risi et al., 2008]. As will be discussed in section 4.4, our 
252 data suggest that while mainly reflecting rainfall amount, changes in the dominant moisture

253 source also contributed to isotopic variability in Nile Basin $\delta \mathrm{D}_{\text {wax }}$. Leaf waxes are

254 transported by both eolian and fluvial processes but input via the Nile River is the dominant

255 source to GeoB7702-3.

256 The $\delta \mathrm{D}_{\text {wax }}$ record of GeoB7702-3 reveals large changes of approximately 64\%o during 257 the past $28 \mathrm{ka} \mathrm{BP}$ (Fig. 4f), with ice volume corrected values ranging from $-172 \%$ o to -

$258108 \%$, suggesting significant hydrological variability in the Nile Basin. While $\delta \mathrm{D}_{\text {wax }}$ 259 reflects the isotopic composition of precipitation, additional physiological and 260 environmental factors can modify the isotopic signal including isotopic enrichment under 261 arid conditions from evapotranspiration [Sachse et al., 2012] or soil evaporation [Schefuß 262 et al., 2005; Sachse et al., 2012] as well as isotopic depletion due to increased precipitation 263 amount in monsoon regions [Risi et al., 2008]. Vegetation type also can exert an influence 264 on $\delta \mathrm{D}_{\text {wax }}$ values as apparent fractionation varies between plant life-forms, which may either 265 amplify or reduce the signal [Sachse et al., 2012]. In GeoB7702-3, from 11-28 ka BP $\delta \mathrm{D}_{\text {wax }}$ 266 and $\delta^{13} \mathrm{C}_{w a x}$ are strongly positively correlated $\left(\mathrm{r}^{2}=0.56\right)$ but from 11-0 ka BP only a weak 267 correlation exists $\left(\mathrm{r}^{2}=0.19\right)$ suggesting that during the Holocene large fluctuations in $\delta \mathrm{D}_{\text {wax }}$ 268 were not driven by changes in vegetation type. Although the $\delta \mathrm{D}_{\text {wax }}$ and $\delta^{13} \mathrm{C}_{w a x}$ track each 269 other prior to the Holocene, given that $\delta^{13} \mathrm{C}_{w a x}$ values vary by only $1.5 \%$ in the interval 270 from 11-28 ka BP, vegetation changes were not a main factor driving variability in the $271 \delta \mathrm{D}_{\text {wax }}$ in the older portion of the core (Supplementary Material).

272 The overall $\delta \mathrm{D}_{\text {wax }}$ record suggests arid conditions in the Nile Basin from 28 to $16 \mathrm{ka}$ 273 BP. Within this interval, the highest $\delta \mathrm{D}_{\text {wax }}$ values of the entire record are noted during 274 Heinrich Stadials (HS) 2 and 1 (Fig. 4). After HS1, a trend to lower $\delta D_{\text {wax }}$ values occurs 
275 until $12 \mathrm{ka} \mathrm{BP}$ when a reversal to higher $\delta \mathrm{D}_{\text {wax }}$ values denotes the onset of the Younger

276 Dryas. Between 11 and 9.1 ka BP, a dramatic shift of ca. $-40 \%$ occurs, marking the AHP,

277 which is subsequently followed by an overall trend to increasingly higher $\delta \mathrm{D}_{\text {wax }}$ values

278 toward the present.

279 Continental-scale changes in vegetation type in tropical Africa are mainly driven by 280 precipitation and thus it might be expected that $\delta^{13} \mathrm{C}_{\text {wax }}$ should closely track changes in $281 \delta \mathrm{D}_{\text {wax. }}$ Overall trends in $\delta \mathrm{D}_{\text {wax }}$ and $\delta^{13} \mathrm{C}_{\text {wax }}$ are similar in the interval prior to $11 \mathrm{ka} \mathrm{BP}$ with 282 increased $\mathrm{C}_{4}$ inputs noted concurrently with high $\delta \mathrm{D}_{\text {wax }}$ values, indicating arid conditions 283 (Fig. 4; Supplementary Material). However, the two proxies diverge in the Holocene when 284 during the AHP a shift to increased contributions of $\mathrm{C}_{4}$ plants is noted followed by a gradual 285 shift to increased $\mathrm{C}_{3}$ inputs toward the present. This pattern has previously been observed 286 in the Nile Basin and is attributed to the northward migration of the rain belt during the 287 AHP, which caused the expansion of $\mathrm{C}_{4}$ vegetation into previously barren regions of the 288 Sahara [Blanchet et al., 2014].

289 We examined branched GDGTs to reconstruct mean annual air temperature (MAAT) 290 and soil $\mathrm{pH}$ within the Nile Basin using the MBT'/CBT [Peterse et al., 2012] and CBT 291 indices [Weijers et al., 2007], respectively (Fig. 4b and h). The CBT Index provides an 292 independent hydroclimate proxy and can be used as a relative indicator of wet versus arid 293 conditions because higher precipitation leads to lower (more acidic) $\mathrm{pH}$ values [Weijers et 294 al., 2007]. Overall trends in the CBT-derived soil $\mathrm{pH}$ record (Fig. 4h) track the $\delta \mathrm{D}_{\text {wax }}$ record 295 (Fig. 4f). However, within the AHP interval, the soil pH record reflects a more gradual 296 onset (starting at ca. $11 \mathrm{ka} \mathrm{BP}$ ) and termination (at ca. $5.7 \mathrm{ka} \mathrm{BP}$ ) of maximum wet 297 conditions in comparison to the $\delta \mathrm{D}_{\text {wax }}$ record, which indicates an abrupt shift to the most 
298 depleted values of the entire record in the early Holocene from ca. 9 to $7 \mathrm{ka}$ BP (section

299 4.4). Likewise, a gradual onset and termination of the AHP is noted in the MBT'/CBT300 derived MAAT record.

301 Another hydroclimate proxy is provided by elemental data from XRF core scanning, 302 yielding information on past variability in Nile River flow. High iron $(\mathrm{Fe})$ content in the 303 EM Sea is attributed to high Nile flood intensity [Revel et al., 2010]. Likewise, the ratios 304 of titanium $(\mathrm{Ti})$ or iron $(\mathrm{Fe})$ to aluminum $(\mathrm{Al})$ in the EM Sea are attributed to fluctuations 305 in material deriving from the Ethiopian Highlands [Box et al., 2011]. Ti to calcium (Ca) 306 ratios are often used to examine terrigenous versus marine input. In GeoB7702-3 the lowest $307 \mathrm{Fe} / \mathrm{Al}$ and $\mathrm{Ti} / \mathrm{Ca}$ ratios are from ca. 15.7 to $14 \mathrm{ka} \mathrm{BP}$ signaling low runoff (Fig. $4 \mathrm{a}$ ). We 308 note that the Ti/Al and $\mathrm{Fe} / \mathrm{Ca}$ ratios (not plotted) yield exactly the same trends as the $\mathrm{Fe} / \mathrm{Al}$ 309 and Ti/Ca records, respectively. At around 17-16 ka BP, Lakes Tana and Victoria, the 310 sources of the Blue and While Nile, desiccated [Lamb et al., 2007; Stager et al., 2011]. The 311 re-establishment of overflow of Lake Victoria occurred at 14.5-14 ka BP [Williams et al., 312 2006] while overflow at Lake Tana is dated to $15.3 \mathrm{ka}$ BP [Marshall et al., 2011]. The 313 desiccation and subsequent overflow of Lakes Victoria and Tana is the main feature 314 captured by the XRF records rather than the AHP. Likely, the XRF records are mainly 315 sensitive to conditions at Lake Tana as the majority of Nile River sediment derives from 316 the Ethiopian highlands [Foucault and Stanley, 1989].

317 A final hydroclimate proxy is provided by the MS record. Bulk soil MS provides a 318 proxy for rainfall based on the premise that MS reflects the degree of pedogenesis, which 319 increases with increasing rainfall [Balsam et al., 2011]. Furthermore, it has been proposed 320 that MS provides a quantitative rainfall proxy when appropriate statistical models are 
321 developed and calibrated for a specific region, necessary because relationships between

322 MS and rainfall may be either linear or non-linear [Maher and Possolo, 2013]. We find

323 that the GeoB7702-3 MS record is in close agreement with the $\delta \mathrm{D}_{\text {wax }}$ record, supporting its

324 use as a rainfall proxy (Fig. 4). A modern calibration study and model of the MS-rainfall

325 relationship has not yet been conducted for the Nile River Basin and thus we cannot

326 calculate paleo-precipitation amounts from the MS record. However, it appears this is a

327 promising avenue of future research. To date the MS-precipitation proxy has been studied

328 in soils but our results suggest it also may be applicable to marine settings receiving a large

329 influx of terrestrial material, such as the EM Sea.

330

331 4.3. Proxy responses to hydroclimate variability

332 An interesting feature of our data is that individual proxies analyzed on the same

333 samples reveal differences in their responses (abrupt or gradual) to the same hydroclimate

334 events. For example, if we had only examined brGDGTs (MAAT and soil $\mathrm{pH}$ ), we would

335 conclude that the AHP in the Nile Basin was a gradual event (Fig. 4). Likewise, if we had

336 only examined $\delta \mathrm{D}_{\text {wax }}$ we might conclude that an abrupt event occurred from ca. 9-7 ka BP

337 (Fig. 4). Thus the onset and termination of the AHP at a single site may be mutually

338 registered as both an abrupt and gradual climate transition, depending on proxy used. Such

339 differences among proxies are not unexpected as each has its own set of associated

340 uncertainties and potential confounding factors, and different parts of the ecosystem (e.g.

341 soils versus vegetation) may not exhibit the same response to environmental variability.

342 Furthermore, different organic compound classes within the same sample can represent 
343 material of different ages as indicated by compound-specific radiocarbon investigations

344 [Eglinton et al., 1997].

345 A wide variety of proxies have been utilized at different locations to investigate the

346 AHP, with some studies using a single proxy only, raising the possibility that some of the

347 disagreement surrounding the abruptness of the AHP between studies may be partially

348 related to the type of proxy examined. Although the Nile River integrates material along a

349 vast, climatically diverse, catchment and thus perhaps is a non-ideal setting to examine

350 differences in proxy response to a single event, multiproxy studies from lacustrine sites

351 lend support this idea. At Lake Victoria, the transition to the AHP is marked by an abrupt

$35223 \%$ shift in $\delta \mathrm{D}_{\text {wax }}$ occurring in 600 years and concurrently pollen assemblages indicate an

353 abrupt shift from a grass dominated ecosystem to a tree and shrub dominated ecosystem

354 [Berke et al., 2012]. In contrast, $\delta^{13} \mathrm{C}_{\text {wax }}$ values remain unchanged through this transition

355 [Berke et al., 2012]. At Lake Tana, Ti XRF counts (a proxy for drought) indicate aridity

356 during the Younger Dryas but $\delta \mathrm{D}_{\text {wax }}$ exhibits little variability at this time; additionally, the

357 duration of humid conditions recorded by these two proxies differs [Costa et al., 2014].

358 The Lake Challa record displays significant differences between $\delta \mathrm{D}_{w a x}$, which indicates an

359 abrupt onset and termination of the AHP, and the BIT Index (used as a runoff proxy at this

360 site), which exhibits a more gradual transition from the early- to mid-Holocene [Tierney et

361 al., 2011a]. These examples demonstrate that different proxies measured at a single site

362 can record varying abrupt or gradual responses to, or different durations of, the same event.

363 As more high-resolution paleoclimate records continue to be generated, differences in the

364 sensitivity of individual proxies to environmental variability is a factor that should be

365 considered with regard to the debate surrounding the abruptness of the AHP. Future 
366 multiproxy investigations, as well as compound-specific ${ }^{14} \mathrm{C}$ investigations, will help

367 further elucidate the responses of individual proxies to hydroclimate events.

369 4.4. The African Humid Period

370 The transition from arid conditions of the Late Pleistocene into the wet phase of the

371 early Holocene at our core site is documented by multiple hydroclimate proxies although

372 variability in the timing and duration of the transition into and out of the AHP is evident

373 (Figs. 4, 5). While a gradual $2^{\circ} \mathrm{C}$ increase in MAAT occurred from 14 to ca. 8 ka BP

374 followed by a $2.5^{\circ} \mathrm{C}$ decease until $4 \mathrm{ka} \mathrm{BP}$ (Fig. $4 \mathrm{~d}$ ), most other proxies indicate a more

375 rapid or abrupt transition at ca. $11 \mathrm{ka}$ BP. The overall structure of our $\delta \mathrm{D}_{\text {wax }}$ record, which

376 exhibits an appreciable $40 \%$ decrease from 11 to $9.1 \mathrm{ka}$, follows the $\mathrm{Ba} / \mathrm{Ca}$ record of

377 Weldeab et al. [2014] (Fig. 5), a proxy used to track Nile discharge, reflecting gradual

378 hydroclimate change in response to orbital forcing and associated migrations of the tropical

379 rainbelt. $\delta^{18} \mathrm{O}$ records of the planktonic foraminifer G. ruber from the EM Sea, reflecting

380 variability in Nile River discharge, indicate a similar pattern with peak runoff in the early

381 Holocene followed by a gradual decline in runoff tracking insolation [Hennekam et al.,

382 2014; Blanchet et al., 2014]. However, abrupt responses are also evident in our records.

383 Between 9.7 and $9.1 \mathrm{ka} \mathrm{BP}, \delta \mathrm{D}_{\text {wax }}$ values decrease by $20 \%$ in ca. 600 years. Likewise,

384 between 7.5 and $6.7 \mathrm{ka} \mathrm{BP}$, a $20 \%$ increase in $\delta \mathrm{D}_{\text {wax }}$ is noted. Thus, in the Nile Basin $\delta \mathrm{D}_{\text {wax }}$

385 record, the peak phase of the AHP occurred from ca. 9 to $7 \mathrm{ka} \mathrm{BP}$ and its onset and

386 termination were abrupt. The soil $\mathrm{pH}, \mathrm{MS}$ and EM SST records (Fig. 4e, 4g, 4h) also

387 indicate an excursion during this peak phase of the AHP. In each of these records the abrupt 
388 transitions into and out of the peak humid phase are superimposed on a longer, more 389 progressive shift in East African hydroclimate.

390 The external cause of the AHP is attributed to increased northern hemisphere summer

391 insolation and associated feedbacks, which intensified land-sea temperature gradients and 392 summer monsoonal circulation, and shifted the tropical rainbelt to the north during boreal 393 summer [Kutzbach and StreetPerrott, 1985; Claussen et al., 1999]. However, it is 394 recognized that migrations of the tropical rainbelt likely were not the sole cause of 395 hydrological fluctuations [Tierney and deMenocal, 2013; Stager et al., 2011]. Recent 396 studies have provided evidence for the role of the Congo Air Boundary (CAB) in 397 modulating precipitation and contributing to abrupt hydroclimate variability in East Africa

398 [Tierney et al., 2011a; Junginger et al., 2014; Costa et al., 2014]. Precipitation over the 399 Nile Basin derives from Atlantic and Indian Ocean sources [Gimeno et al., 2010; 400 Camberlin, 2009; Tierney et al., 2011b]. At the present day, precipitation in the Congo 401 Basin is depleted (by about $-25 \%$ ) in comparison to Indian Ocean-derived precipitation 402 falling at Lake Challa (Kenya/Tanzania) [Tierney et al., 2011b]. A modeling study of 403 Eemian African tropical and subtropical moisture transport concluded that stronger 404 moisture advection from the Atlantic resulted in isotopically depleted rainfall in East Africa 405 [Herold and Lohmann, 2009]. The Eemian scenario can be considered an analog to the 406 early Holocene AHP. The authors found that differential surface heating occurs driven by 407 excess NH summer insolation, which warms North Africa and increases the meridional 408 temperature gradient [Herold and Lohmann, 2009]. In turn, this produces a pressure 409 gradient and induces increased zonal flow. The enhanced zonal flow delivers a greater 410 amount of moisture from the Atlantic to East Africa [Herold and Lohmann, 2009]. 
411 We suggest that the abrupt shift in the $\delta \mathrm{D}_{\text {wax }}$ record from 9-7 ka BP could result from a

412 shift in the dominant moisture source, consistent with the model described above. A switch

413 in the dominant moisture source is a mechanism that can account for abrupt isotopic

414 changes thereby contributing to non-linear behavior of $\delta \mathrm{D}_{\text {wax. }}$. The Nile Basin $\delta \mathrm{D}_{\text {wax }}$ record

415 points to increased inputs of Atlantic Ocean-derived moisture (i.e., depleted $\delta \mathrm{D}$ ) during the

416 peak phase (9-7 ka BP) of the AHP, which could result from an eastward shifted CAB.

417 Indeed, recent studies provide evidence that during the early Holocene the $\mathrm{CAB}$ delivered

418 more Atlantic derived moisture to parts of the East African Rift Valley presently located

419 outside of the influence of the CAB [Junginger et al., 2014; Costa et al., 2014]. The abrupt

420 excursion to the lowest $\delta \mathrm{D}_{\operatorname{wax}}$ values of the entire record from ca. 7-9 ka BP may reflect a

421 shift to relatively larger inputs of Atlantic Ocean sourced moisture within the Nile Basin,

422 in combination with increased precipitation amount driven by increased northern

423 hemisphere summer insolation.

\section{$425 \quad 4.5 . \quad$ Heinrich Stadial 1}

426 Our multiproxy records reveal that a number of striking hydroclimate changes occurred

427 in the Nile Basin during the transition from the LGM to the Holocene with the most severe

428 aridity occurring during Heinrich Stadials (HS) (Fig. 4), in agreement with previous studies

429 [Stager et al., 2011; Mulitza et al., 2008; Tierney and deMenocal, 2013; Tierney et al., 430 2008]. A remarkable feature is observed during HS1 (ca. 19-14.6 ka BP [Stanford et al.,

$4312011]$ ) as the onset and termination of this event in the $\delta \mathrm{D}_{w a x}$ and MS records occurs prior

432 to the onset of HS1 noted in the soil pH, MAAT, XRF or EM SST records (Fig. 4 \& 6),

433 suggesting two distinct phases occurring within HS1. In nearly all records HS1 is registered 
434 as abrupt event with the onset and termination occurring over ca. 200 to 1,000 years. We

435 cannot rule out potential age discrepancies between different proxies; however, the timing

436 of two phases observed in the Nile Basin records is in good agreement with other studies

437 that have noted a two-phase HS1 recorded by a single proxy [Bard et al., 2000]. Thus, our

438 data lend support to a growing body of evidence that HS1 evolved in two [Naughton et al.,

439 2009; Broecker and Putnam, 2012] or three distinct phases [Bouimetarhan et al., 2012;

440 Stanford et al., 2011; Bard et al., 2000]. Hereafter we refer to the earlier phase of HS1

441 interval as HS1a (ca. 17.5 to $16 \mathrm{ka} \mathrm{BP}$ ) and the latter phase (ca. 16-14.5 ka BP) as HS1b

442 (Fig. 4 and 6).

443 High $\delta \mathrm{D}_{\text {wax }}$ values during HS1a could result from increased temperature, a shift in the

444 dominant vegetation type, a precipitation reduction or a shift in the dominant moisture

445 source. Temperature can be excluded as the interval prior to ca. $16 \mathrm{ka} \mathrm{BP}$ is characterized

446 by the lowest SST and MAATs of the entire record. Similarly, vegetation is not the main

447 factor contributing to deuterium enrichment as discussed previously. As other Nile Basin

448 proxies and numerous North African paleoclimate records indicate maximum aridity

449 occurring during HS1b (Fig. 4, discussion below), a precipitation reduction is unlikely to

450 be the sole cause of the excursion to maximum $\delta \mathrm{D}_{\text {wax }}$ values. We therefore suggest that

451 during HS1a the Nile Basin experienced a shift in the dominant moisture source and

452 received relatively less inputs of Atlantic-derived moisture or greater amounts of Indian

453 Ocean-derived moisture. Furthermore, although chronological differences cannot be ruled

454 out when comparing multiple sites, we note that the excursion in the Nile Basin $\delta \mathrm{D}_{\text {wax }}$

455 record during HS1a appears to be synchronous with the Lake Tanganyika $\delta \mathrm{D}_{\text {wax }}$ record

456 [Tierney et al., 2008], which mainly falls under the influence of the Indian Ocean, where 
457 HS1 terminates at $15.8 \mathrm{ka} \mathrm{BP}$ (Fig. 5c and f). A westward shifted position of the CAB 458 could produce such an isotopic shift over the Nile Basin.

459 The most extreme aridity of the past $28 \mathrm{ka}$ BP in North Africa occurred during HS1b, 460 coincident with the pronounced interval of minimum SSTs in the EM [Castañeda et al., 461 2010] and Red Seas [Arz et al., 2003]. The role of EM SST in influencing rainfall in North 462 Africa, on decadal or longer timescales, is well-established [Rowell, 2003]. Low EM SST

463 reduces the moisture content of the lower troposphere, leading to reduced southward 464 moisture advection and decreased low-level moisture convergence over the Sahel, thereby 465 reducing precipitation [Rowell, 2003]. Synchronous with low EM SST, a major excursion 466 is seen in the XRF elemental ratios (Fig. 4), attributed to the desiccation of Lakes Tana 467 [Marshall et al., 2011] and Victoria [Stager et al., 2011] and a dramatic reduction in Nile 468 flow. During Heinrich Stadials, reduced Atlantic Meridional Overturning Circulation 469 (AMOC) and associated North Atlantic cooling caused a southward shift of the tropical 470 rainbelt, stronger NE trade winds, and intensified moisture export by the African Easterly 471 Jet [Mulitza et al., 2008]. The NE trade winds were particularly strong during the latter part 472 of HS1, from ca. 16-15 ka BP, as was the African Easterly Jet (AEJ), increasing moisture 473 export from continental Africa [Bouimetarhan et al., 2012; Mulitza et al., 2008] (Fig. 6).

474 In the Arabian Peninsula region exceptionally dry and dusty conditions are noted during 475 HS1b [Deplazes et al., 2014].

476 Interestingly, the Nile Basin $\mathrm{MBT}^{\prime} / \mathrm{CBT}$ MAAT record indicates increased 477 temperatures during the HS1b interval, coincident with low SST observed in the EM 478 [Castañeda et al., 2010] and Red Seas [Arz et al., 2003]. It is unlikely that the Nile Basin 479 experienced warming at this time. Rather, the apparent warming is attributed to an 
480 equatorward shift in the dominant source area of material transported by the Nile River

481 following the desiccation of Lake Tana with decreased runoff from the colder Ethiopian

482 Highlands and relatively higher contributions of White Nile material (Figs. 3, 4).

483

$484 \quad$ 4.6. Influence of hydroclimate variability on human populations

485 The dramatic hydroclimate changes that took place in North Africa during the AHP had 486 a major impact on human populations as documented by the archaeological record [Kuper 487 and Kröpelin, 2006; Vermeersch and Van Neer, 2015]. We note that the peak phase of the 488 AHP in the Nile Basin corresponds to the abandonment of settlements in the Nile Valley 489 of Egypt (Fig. 5), likely due to the prevalence of hazardous flood events along the Nile 490 [Kuper and Kröpelin, 2006]. The termination of the peak AHP phase is consistent with the 491 reoccupation of Nile Valley settlements at 7.5 ka BP. In the late Holocene, the Old World 492 Kingdom collapsed at ca. 4.2 ka BP [Stanley et al., 2003]. High variability is observed in 493 some of the Nile Basin records during the late Holocene, particularly in the soil $\mathrm{pH}$ and $494 \delta \mathrm{D}_{\text {wax }}$ records, likely reflecting alternating floods and droughts that are registered in 495 Egyptian chronology [Stanley et al., 2003].

496 Two main periods of human occupation are recognized in the Upper Egyptian Nile 497 Valley during the Late Pleistocene; around the LGM (23-20 ka BP) and around HS1 (ca. 498 16-14 ka BP) [Vermeersch and Van Neer, 2015]. At these times, it is hypothesized that 499 aeolian sands created dams at several places along the Nile, allowing for the formation of

500 lakes and suitable environments for human occupation in an otherwise extremely arid 501 setting [Vermeersch and Van Neer, 2015]. The influence of aridity during HS1 on human 502 populations is debated [Stager et al., 2011; Thomas et al., 2012]. Stager et al. [2011] 
503 describe HS1 as "one of the most intense and extensive" droughts of the past 50 ka and

504 hypothesize that this event had a major impact on Paleolithic cultures. Conversely, Thomas

505 et al. [2012] note that across the African continent conditions are variable at the time of

506 HS1 and instead postulate that environmental variability played a major role in influencing

507 modern human behavior and evolution. While our new records cannot directly address this

508 debate, certainly a large portion of East Africa north of the equator experienced abrupt and

509 severe aridity during HS1 including the Nile Basin.

510

\section{$511 \quad$ 5. Conclusions}

512 Our multi-proxy study demonstrates that dramatic hydroclimate variability occurred in

513 Nile Basin during the past 28,000 years. Overall, our new Nile Basin records support other

514 North African hydroclimate records while providing information regarding shifts in the

515 dominant sources of material delivered to the EM Sea via the Blue Nile and the White Nile.

516 While $\delta \mathrm{D}_{\text {wax }}$ is often interpreted to reflect precipitation amount in the African tropics, our

517 data suggest that shifting moisture sources, related to migrations of the tropical rainbelt

518 and $\mathrm{CAB}$, also contributed to isotopic variability. As $\delta \mathrm{D}_{\text {wax }}$ may behave non-linearly due

519 to the additional influence of changing moisture sources, care should be taken when

520 interpreting $\delta \mathrm{D}_{\text {wax }}$ records from areas falling under the influence of isotopically distinct

521 moisture sources. We note that at several North African sites, hydroclimate records reveal

522 both abrupt and gradual responses to single events and these differential responses appear

523 to be proxy-dependent, potentially contributing to the debate surrounding the abruptness

524 of the AHP. Our new records provide strong evidence for severe aridity in the Nile Basin

525 during HS1, an event that evolved in two phases, whereas maximum wet conditions 
526 occurred during the AHP from ca. 9-7 ka BP. Zonal migrations of the CAB likely

527 contributed to the extreme hydroclimate fluctuations observed during these events, which

528 may have impacted Paleolithic cultures residing along the Nile corridor.

529

\section{Acknowledgements}

531 We thank Marianne Baas, Ellen Hopmans, Jort Ossebaar and Michiel Kienhuis for

532 analytical assistance. We thank two anonymous reviewers for thoughtful comments that

533 improved the manuscript. Research funding was provided by NEBROC-2. Samples from

534 GeoB7702-3 were supplied through the assistance of the University of Bremen,

535 Geosciences Department and MARUM. This work was supported by the DFG-Research

536 Center/Excellence Cluster "The Ocean in the Earth System". 


\section{References}

538 Amit, R., Y. Enzel, O. Crouvi, O. Simhai, A. Matmon, N. Porat, E. McDonald, and A. R.

539 Gillespie (2011), The role of the Nile in initiating a massive dust influx to the Negev late

540 in the middle Pleistocene, Geological Society of America Bulletin, 123(5-6), 873-889.

541 Arz, H. W., J. Pätzold, P. J. Müller, and M. O. Moammar (2003), Influence of Northern

542 Hemisphere climate and global sea level rise on the restricted Red Sea marine environment

543 during termination I, Paleoceanography, 18(2).

544 Balsam, W. L., B. B. Ellwood, J. Ji, E. R. Williams, X. Long, and A. El Hassani (2011),

545 Magnetic susceptibility as a proxy for rainfall: worldwide data from tropical and temperate

546 climate, Quaternary Science Reviews, 30(19), 2732-2744.

547 Bard, E. (2013), Out of the African Humid Period, Science, 342(6160), 808-809.

548 Bard, E., F. Rostek, J.-L. Turon, and S. Gendreau (2000), Hydrological impact of Heinrich

549 events in the subtropical northeast Atlantic, Science, 289(5483), 1321-1324.

550 Ben Israel, M., Y. Enzel, and Y. Erel (2015), Provenance of the various grain-size fractions

551 in the Negev loess and potential changes in major dust sources to the Eastern

552 Mediterranean, Quaternary Research, 83(1), 105-115.

553 Berke, M. A., T. C. Johnson, J. P. Werne, K. Grice, S. Schouten, and J. S. Sinninghe Damsté

554 (2012), Molecular records of climate variability and vegetation response since the Late

555 Pleistocene in the Lake Victoria basin, East Africa, Quaternary Science Reviews, 55, 59-

55674.

557 Blanchet, C. L., R. Tjallingii, M. Frank, J. Lorenzen, A. Reitz, K. Brown, T. Feseker, and W.

558 Brückmann (2013), High-and low-latitude forcing of the Nile River regime during the

559 Holocene inferred from laminated sediments of the Nile deep-sea fan, Earth and Planetary

560 Science Letters, 364, 98-110.

561 Blanchet, C. L., M. Frank, and S. Schouten (2014), Asynchronous changes in vegetation,

562 runoff and erosion in the Nile River Watershed during the Holocene, PLoS ONE, 9(12),

563 e115,958, doi:10.1371/journal.pone. 0115958.

564 Bouimetarhan, I., M. Prange, E. Schefuß, L. Dupont, J. Lippold, S. Mulitza, and K. Zonneveld

565 (2012), Sahel megadrought during Heinrich Stadial 1: evidence for a three-phase evolution

566 of the low-and midlevel West African wind system, Quaternary Science Reviews, 58, 6656776. 
568 Box, M., M. Krom, R. Cliff, M. Bar-Matthews, A. Almogi-Labin, A. Ayalon, and M. Paterne 569 (2011), Response of the Nile and its catchment to millennial-scale climatic change since 570 the LGM from $\mathrm{Sr}$ isotopes and major elements of East Mediterranean sediments, 571 Quaternary Science Reviews, 30(3), 431-442.

572 Broecker, W., and A. E. Putnam (2012), How did the hydrologic cycle respond to the two573 phase mystery interval?, Quaternary Science Reviews, 57, 17-25.

574 Camberlin, P. (2009), Nile Basin Climates, in The Nile, pp. 307-333, Springer.

575 Castañeda, I. S., S. Mulitza, E. Schefuß, R. A. L. dos Santos, J. S. Sinninghe Damsté, and S. 576 Schouten (2009), Wet phases in the Sahara/Sahel region and human migration patterns in 577 North Africa, Proceedings of the National Academy of Sciences, 106(48), 20,159-20,163.

578 Castañeda, I. S., E. Schefuß, J. Pätzold, J. S. Sinninghe Damsté, S. Weldeab, and S. Schouten 579 (2010), Millennial-scale sea surface temperature changes in the eastern Mediterranean 580 (Nile River Delta region) over the last 27,000 years, Paleoceanography, 25(1).

581 Claussen, M., C. Kubatzki, V. Brovkin, A. Ganopolski, P. Hoelzmann, and H.-J. Pachur 582 (1999), Simulation of an abrupt change in Saharan vegetation in the mid-Holocene, 583 Geophysical Research Letters, 26(14), 2037-2040.

584 Costa, K., J. Russell, B. Konecky, and H. Lamb (2014), Isotopic reconstruction of the African 585 Humid Period and Congo Air Boundary migration at Lake Tana, Ethiopia, Quaternary 586 Science Reviews, 83(0), 58 - 67, doi:http://dx.doi.org/10.1016/j.quascirev.2013.10.031.

587 Dansgaard, W. (1964), Stable isotopes in precipitation, Tellus, 16(4), 436- 468.

588 deMenocal, P., J. Ortiz, T. Guilderson, J. Adkins, M. Sarnthein, L. Baker, and M. Yarusinsky 589 (2000), Abrupt onset and termination of the African Humid Period:: rapid climate 590 responses to gradual insolation forcing, Quaternary Science Reviews, 19(15), 347 - 361, 591 doi:http://dx.doi.org/ 10.1016/S0277-3791(99)00081-5.

592 Deniel, C., and C. Pin (2001), Single-stage method for the simultaneous isolation of lead and 593 strontium from silicate samples for isotopic measurements, Analytica Chimica Acta, $594 \quad 426(1), 95-103$.

595 Deplazes, G., A. Lückge, J.-B. W. Stuut, J. Pätzold, H. Kuhlmann, D. Husson, M. Fant, and 596 G. H. Haug (2014), Weakening and strengthening of the Indian monsoon during Heinrich 597 events and Dansgaard-Oeschger oscillations, Paleoceanography, 29(2), 99-114. 
598 Eglinton, G., and R. J. Hamilton (1967), Leaf epicuticular waxes, Science, 156(3780), 1322 5991335.

600 Eglinton, T. I., Benitez-Nelson, B. C., Pearson, A., McNichol, A. P., Bauer, J. E., and Druffel, 601 E. R. (1997), Variability in radiocarbon ages of individual organic compounds from marine 602 sediments. Science, 277, 796-799.

603 Foucault, A., and D. J. Stanley (1989), Late Quaternary palaeoclimatic oscillations in East 604 Africa recorded by heavy minerals in the Nile delta, Nature, 339, 44-46.

605 Gimeno, L., A. Drumond, R. Nieto, R. M. Trigo, and A. Stohl (2010), On the origin of 606 continental precipitation, Geophysical Research Letters, 37(13).

607 Hennekam, R., T. Jilbert, B. Schnetger, and G. J. Lange (2014), Solar forcing of Nile 608 discharge and sapropel S1 formation in the early to middle Holocene eastern 609 Mediterranean, Paleoceanography, 29(5), 343-356.

610 Herold, M., and G. Lohmann (2009), Eemian tropical and subtropical African moisture 611 transport: an isotope modelling study, Climate dynamics, 33(7-8), 1075-1088.

612 Junginger, A., S. Roller, L. A. Olaka, and M. H. Trauth (2014), The effects of solar irradiation 613 changes on the migration of the Congo Air Boundary and water levels of paleo-Lake 614 Suguta, Northern Kenya Rift, during the African Humid Period (15-5 ka BP), 615 Palaeogeography, Palaeoclimatology, Palaeoecology, 396(0), 1 - 16, 616 doi:http://dx.doi.org/10.1016/j. palaeo.2013.12.007.

617 Kim, J.-H., S. Schouten, M. Rodrigo-Gámiz, S. Rampen, G. Marino, C. Huguet, P. Helmke, 618 R. Buscail, E. C. Hopmans, J. Pross, F. Sangiorgi, J. B. Middelburg, and J. S. Sinninghe 619 Damsté (2015), Influence of deepwater derived isoprenoid tetraether lipids on the 620 paleothermometer in the Mediterranean Sea, Geochimica et Cosmochimica Acta, 150(0), 621125 - 141, doi:http://dx.doi.org/10.1016/j.gca.2014.11.017.

622 Krom, M. D., J. D. Stanley, R. A. Cliff, and J. C. Woodward (2002), Nile River sediment 623 fluctuations over the past $7000 \mathrm{yr}$ and their key role in sapropel development, Geology, $62430(1), 71-74$.

625 Kuhlmann, H., H. Meggers, T. Freudenthal, and G. Wefer (2004), The transition of the 626 monsoonal and the N Atlantic climate system off NW Africa during the Holocene, 627 Geophysical Research Letters, 31(22), L22,204. 
628 Kuper, R., and S. Kröpelin (2006), Climate-controlled Holocene occupation in the Sahara: 629 motor of Africa's evolution, Science, 313(5788), 803-807.

630 Kutzbach, J. E., and F. A. Street-Perrott (1985), Milankovitch forcing of fluctuations in the 631 level of tropical lakes from 18 to 0 kyr BP, Nature, 317, 130-134.

632 Lamb, H. F., C. R. Bates, P. V. Coombes, M. H. Marshall, M. Umer, S. J. Davies, and E. 633 Dejen (2007), Late Pleistocene desiccation of Lake Tana, source of the Blue Nile, 634 Quaternary Science Reviews, 26(3), 287-299.

635 Laskar, J., P. Robutel, F. Joutel, M. Gastineau, A. Correia, B. Levrard, et al. (2004), A long636 term numerical solution for the insolation quantities of the Earth, Astronomy \& 637 Astrophysics, 428(1), 261-285.

638 Maher, B., and A. Possolo (2013), Statistical models for use of palaeosol magnetic properties 639 as proxies of palaeorainfall, Global and Planetary Change, 111, 280-287.

640 Marshall, M. H., H. F. Lamb, D. Huws, S. J. Davies, R. Bates, J. Bloemendal, J. Boyle, M. J. 641 Leng, M. Umer, and C. Bryant (2011), Late Pleistocene and Holocene drought events at 642 Lake Tana, the source of the Blue Nile, Global and Planetary Change, 78(3), 147-161.

643 McGee, D., P. deMenocal, G. Winckler, J. Stuut, and L. Bradtmiller (2013), The magnitude, 644 timing and abruptness of changes in North African dust deposition over the last 20,000 yr, 645 Earth and Planetary Science Letters, 371, 163-176.

646 Mikova, J., and P. Denkova (2007), Modified chromatographic separation scheme for Sr and 647 Nd isotope analysis in geological silicate samples, Journal of Geosciences, 52(3-4), 221648226.

649 Muhs, D. R., J. Roskin, H. Tsoar, G. Skipp, J. R. Budahn, A. Sneh, N. Porat, J.-D. Stanley, I. 650 Katra, and D. G. Blumberg (2013), Origin of the Sinai-Negev erg, Egypt and Israel: 651 mineralogical and geochemical evidence for the importance of the Nile and sea level 652 history, Quaternary Science Reviews, 69, 28-48.

653 Mulitza, S., M. Prange, J.-B. Stuut, M. Zabel, T. von Dobeneck, A. C. Itambi, J. Nizou, M. 654 Schulz, and G. Wefer (2008), Sahel megadroughts triggered by glacial slowdowns of 655 Atlantic meridional overturning, Paleoceanography, 23(4).

656 Naughton, F., M. Sánchez Goñi, M. Kageyama, E. Bard, J. Duprat, E. Cortijo, S. Desprat, B. 657 Malaizé, C. Joly, F. Rostek, et al. (2009), Wet to dry climatic trend in north-western Iberia 658 within Heinrich events, Earth and Planetary Science Letters, 284(3), 329-342. 
659 Pätzold, J., G. Bohrmann, and C. Hübscher (2003), Black Sea - Mediterranean - Red Sea, 660 Cruise No. 52, January 2 - March 27, 2002, Istanbul - Limassol. METEOR-Berichte 03-2, 661 Universität Hamburg, p. 178 pp.

662 Peterse, F., J. van der Meer, S. Schouten, J. W. Weijers, N. Fierer, R. B. Jackson, J.-H. Kim, 663 and J. S. Sinninghe Damsté (2012), Revised calibration of the MBT-CBT 664 paleotemperature proxy based on branched tetraether membrane lipids in surface soils, 665 Geochimica et Cosmochimica Acta, 96, 215-229.

666 Pin, C., D. Briot, C. Bassin, and F. Poitrasson (1994), Concomitant separation of strontium 667 and samarium-neodymium for isotopic analysis in silicate samples, based on specific 668 extraction chromatography, Analytica Chimica Acta, 298(2), 209-217.

669 Revel, M., E. Ducassou, F. Grousset, S. Bernasconi, S. Migeon, S. Revillon, J. Mascle, A. 670 Murat, S. Zaragosi, and D. Bosch (2010), 100,000 years of African monsoon variability 671 recorded in sediments of the Nile margin, Quaternary Science Reviews, 29(11), 13426721362.

673 Risi, C., S. Bony, and F. Vimeux (2008), Influence of convective processes on the isotopic 674 composition $\left(\delta^{18} \mathrm{O}\right.$ and $\left.\delta \mathrm{D}\right)$ of precipitation and water vapor in the tropics: 2. physical 675 interpretation of the amount effect, Journal of Geophysical Research: Atmospheres, 676 113(D19), 1984-2012.

677 Rowell, D. P. (2003), The impact of Mediterranean SSTs on the Sahelian rainfall season, 678 Journal of Climate, 16(5), 849-862.

679 Sachse, D., I. Billault, G. J. Bowen, Y. Chikaraishi, T. E. Dawson, S. J. Feakins, K. H. 680 Freeman, C. R. Magill, F. A. McInerney, M. T. Van der Meer, et al. (2012), Molecular 681 paleohydrology: interpreting the hydrogen-isotopic composition of lipid biomarkers from 682 photosynthesizing organisms, Annu. Rev. Earth Planet. Sci, 40, 221-249.

683 Schefuß, E., S. Schouten, J. F. Jansen, and J. S. Sinninghe Damsté (2003), African vegetation 684 controlled by tropical sea surface temperatures in the mid-Pleistocene period, Nature, 685 422(6930), 418-421.

686 Schefuß, E., S. Schouten, and R. R. Schneider (2005), Climatic controls on central African 687 hydrology during the past 20,000 years, Nature, 437(7061), 1003-1006.

688 Schefuß, E., H. Kuhlmann, G. Mollenhauer, M. Prange, and J. Pätzold (2011), Forcing of wet 689 phases in southeast Africa over the past 17,000 years, Nature, 480(7378), 509-512. 
690 Shanahan, T. M., N. P. McKay, K. A. Hughen, J. T. Overpeck, B. OttoBliesner, C. W. Heil, 691 J. King, C. A. Scholz, and J. Peck (2015), The time-transgressive termination of the African 692 Humid Period, Nature Geoscience, 8, 140-144.

693 Stager, J. C., D. B. Ryves, B. M. Chase, and F. S. Pausata (2011), Catastrophic drought in the 694 Afro-Asian monsoon region during Heinrich event 1, Science, 331(6022), 1299-1302.

695 Stanford, J., E. Rohling, S. Bacon, A. Roberts, F. Grousset, and M. Bolshaw (2011), A new 696 concept for the paleoceanographic evolution of Heinrich event 1 in the North Atlantic, 697 Quaternary Science Reviews, 30(9), 1047-1066.

698 Stanley, J.-D., M. D. Krom, R. A. Cliff, and J. C. Woodward (2003), Short contribution: Nile 699 flow failure at the end of the Old Kingdom, Egypt: strontium isotopic and petrologic 700 evidence, Geoarchaeology, 18(3), 395- 402.

701 Thomas, D. S., S. L. Burrough, and A. G. Parker (2012), Extreme events as drivers of early 702 human behaviour in Africa? The case for variability, not catastrophic drought, Journal of 703 Quaternary Science, 27(1), 7-12.

704 Tierney, J. E., and M. P. Tingley (2014), A Bayesian, spatially-varying calibration model for 705 the TEX 86 proxy, Geochimica et Cosmochimica Acta, 127, 83-106.

706 Tierney, J. E., J. M. Russell, Y. Huang, J. S. Sinninghe Damsté, E. C. Hopmans, and A. S. 707 Cohen (2008), Northern hemisphere controls on tropical southeast African climate during 708 the past 60,000 years, Science, 322(5899), 252-255.

709 Tierney, J. E., J. M. Russell, J. S. Sinninghe Damsté, Y. Huang, and D. Verschuren (2011a), 710 Late Quaternary behavior of the East African monsoon and the importance of the Congo

711 Air Boundary, Quaternary Science Reviews, 30(78), 798 - 807, 712 doi:http://dx.doi.org/10.1016/j.quascirev.2011.01.017.

713 Tierney, J. E., S. C. Lewis, B. I. Cook, A. N. LeGrande, and G. A. Schmidt (2011b), Model, 714 proxy and isotopic perspectives on the East African Humid Period, Earth and Planetary 715 Science Letters, 307(12), 103 -112, doi:http://dx.doi.org/10.1016/j.eps1.2011.04.038.

716 Tierney, J. E., and P.B. de Menocal (2013), Abrupt shifts in Horn of Africa hydroclimate 717 since the Last Glacial Maximum, Science, 342(6160), 843-846.

718 Vermersch, P.M., and Van Neer, W. (2015), Nile behaviour and Late Palaeolithic humans in 719 Upper Egypt during the Late Pleistocene. Quaternary Science Reviews (in press). 
720 Wang, Y. V., G. Leduc, M. Regenberg, N. Andersen, T. Larsen, T. Blanz, and R. R. Schneider 721 (2013), Northern and southern hemisphere controls on seasonal sea surface temperatures 722 in the Indian Ocean during the last deglaciation, Paleoceanography, 28(4), 619-632.

723 Weijers, J. W. H., S. Schouten, J. C. van den Donker, E. C. Hopmans, and J. S. Sinninghe 724 Damsté (2007), Environmental controls on bacterial tetraether membrane lipid distribution 725 in soils, Geochim. Cosmochim. Acta, 71(3), 703-713, doi:10.1016/j.gca.2006.10.003.

726 Weldeab, S., K.-C. Emeis, C. Hemleben, and W. Siebel (2002), Provenance of lithogenic 727 surface sediments and pathways of riverine suspended matter in the Eastern Mediterranean 728 Sea: evidence from $\left({ }^{143} \mathrm{Nd} /{ }^{144} \mathrm{Nd}\right.$ and ${ }^{87} \mathrm{Sr} /{ }^{86} \mathrm{Sr}$ ratios, Chemical Geology, 186(1), 139-149. 729 Weldeab, S., V. Menke, and G. Schmiedl (2014), The pace of East African monsoon 730 evolution during the Holocene, Geophysical Research Letters, 41(5), 1724-1732.

731 Williams, M., M. Talbot, P. Aharon, Y. Abdl Salaam, F. Williams, and K. Inge Brendeland 732 (2006), Abrupt return of the summer monsoon 15,000 years ago: new supporting evidence 733 from the lower White Nile valley and Lake Albert, Quaternary Science Reviews, 25(19), $734 \quad 2651-2665$. 
737 Figure 1: a) The termination of the early Holocene Humid Period in North Africa. The 738 colored circles indicate sites where the transition out of the African Humid Period is 739 observed to be abrupt (orange), gradual (green) or stepwise (yellow). Note that the study 740 locations depicted by the dots are approximate and in some cases have been shifted slightly 741 where dots overlapped. See the Supplementary Material for the full list of sites and

742 references. b and c) Mean surface winds over Africa in January and July/August. The 743 locations of the Intertropical Convergence Zone (ITCZ) and Congo Air Boundary (CAB) 744 are illustrated. In b and c, the Nile River catchment is indicated by the area outlined in 745 green and the orange star indicates the location of sediment core GeoB7702-3.

747 Figure 2: a) Location of core GeoB7702-3 in the Eastern Mediterranean Sea. The blue box

748 denotes the area expanded in b) and the green shaded area indicates the catchment of the

749 Nile River. b) Close up of the location of core GeoB7702-3. The approximate locations of 750 cores P362/2-33 [Blanchet et al., 2014], core 9509 [Box et al., 2011] and SL 112 [Weldeab 751 et al., 2014] are also shown. The approximate locations of the Sinai/Negev dunes and loess 752 is indicated by the yellow and brown shading, respectively. c) Precipitation regimes within 753 the Nile River catchment, indicated by colors and numbers. The figure is modified from 754 [Camberlin, 2009]. The location of the Blue Nile (BN), the White Nile (WN), Lake Tana 755 (LT), and Lake Victoria (LV) are indicated. From north to south, zone 1 in the northernmost 756 part of Egypt receives winter rains from the Mediterranean; highest rainfall in January 757 amounts to $11 \mathrm{~mm}$ per month. Hereafter, the precipitation numbers provided represent the 758 maximum monthly precipitation for each particular zone and the data derives from 759 [Camberlin, 2009]. Zone 2 receives almost no precipitation throughout the year while zone 7603 captures the northernmost part of the summer rainfall peak in August $(27 \mathrm{~mm}$ ). Zones 4 761 and 5 also experience maximum rainfall in August with zone 5 receiving more precipitation 762 (169 mm) than zone $4(92 \mathrm{~mm})$. Continuing to the south, zone 6 in southern Sudan 763 experiences a longer rainy season with maximum precipitation noted in August (183 mm).

764 Zone 7 western Ethiopia is similar to zone 6 but sees maximum precipitation in July (301 $765 \mathrm{~mm}$ ) and August. Equatorial zones 8 and 9 experience two yearly passages of the ITCZ 
766 and hence two rainy seasons in April (206 mm for zone 9) and November. For information

767 regarding total annual precipitation within the Nile catchment the reader is referred to

768 Camberlin [2009].

769

770 Figure 3: Radiogenic isotopes and sources of material to GeoB7702-3. a) The figure is 771 based on Blanchet et al. [2013] and modified to include the data of Ben Israel et al. [2015].

772 Shaded areas reveal the isotopic values of material derived from the Blue and Atbara Nile,

773 the Sobat, Negev loess, the White Nile, Erythrean and Nubian dust, Saharan and Lybian 774 dust and the Victoria and Albert Nile. All samples of GeoB7702-3 are clearly distinguished 775 from those of dust sources and plot between Blue and White Nile endmembers. b)

776 GeoB7702-3 neodymium (light green squares) and strontium (teal triangles) isotopes. Note 777 the close agreement of the GeoB7702-3 strontium isotope record with that from core 9509 778 (light blue squares; see Fig. 2 for the location of this core), also collected from the Eastern 779 Mediterranean Sea [Box et al., 2011].

781 Figure 4: Selected geochemical records from GeoB7702-3. The gray shading highlights 782 Heinrich Stadials (HS) 1 and 2 and the African Humid Period. Two intervals within HS1, 783 HS1a and HS1b, are indicated by the shading. a) Element intensity ratio of iron (Fe) to 784 aluminum (Al). b) Element intensity ratio of titanium (Ti) to calcium (Ca). c) Leaf wax 785 carbon isotopes $\left(\delta^{13} \mathrm{C}_{w a x}\right)$ measured on the $\mathrm{C}_{31} n$-alkane, the dominant homologue present. 786 d) Mean annual air temperature reconstructed using the MBT'/CBT proxy. e) TEX 86 787 temperature reconstruction from Castañeda et al. [2010] plotted using the calibration of 788 Tierney and Tingley [2014]. e) ${ }^{87} \mathrm{Sr} /{ }^{86} \mathrm{Sr}$ isotope ratio. The arrow indicates relative 789 contributions from the White and Blue Nile. f) Leaf wax deuterium isotopes $\left(\delta \mathrm{D}_{\text {wax }}\right)$ 790 measured on the $\mathrm{C}_{31} n$-alkane corrected for ice volume changes. Lower values are 791 interpreted as indicated increased rainfall or increased input of Atlantic-derived moisture.

792 g) Volume specific magnetic susceptibility (MS) in $\mathrm{e}^{-5}$ SI units. It has been suggested that 793 MS provides a rainfall proxy with higher MS values associated with higher rainfall [Balsam 794 et al., 2011]. h) Soil pH reconstructed from the CBT index. Lower (more acidic) values are 795 indicative of wetter conditions. i) Summer (June, July and August) insolation at $15^{\circ} \mathrm{N}$ 796 [Laskar et al., 2004]. 
798 Figure 5: The African Humid Period (AHP). a) June, July and August (JJA) insolation at $79915^{\circ} \mathrm{N}$ [Laskar et al., 2004]. b) Ba/Ca record of G. ruber in the Levantine Basin of the 800 Eastern Mediterranean Sea from Weldeab et al. [2014]. c) Nile Basin $\delta \mathrm{D}_{\text {wax }}$. Note the 801 abrupt excursion to lower values during the peak phase of the AHP, indicated by the arrow 802 and gray shading. d) Congo Basin $\delta \mathrm{D}_{\text {wax }}\left[\right.$ Schefu $\beta$ et al., 2005]. e) Gulf of Aden $\delta \mathrm{D}_{\text {wax }}$ 803 [Tierney and deMenocal, 2013]. f) Lake Tanganyika $\delta \mathrm{D}_{\text {wax }}$ [Tierney et al., 2008]. g) Lake 804 Victoria $\delta \mathrm{D}_{\text {wax }}$ [Berke et al., 2012]. $\delta \mathrm{D}$ from the Nile and Congo River Basins was measured 805 on the $\mathrm{C}_{31}$ n-alkane while the Gulf of Aden, Lake Tanganyika and Lake Victoria $\delta \mathrm{D}$ records 806 were measured on the $\mathrm{C}_{28}$ fatty acid. The colored bars at the top indicate phases of 807 occupation (O) and abandonment (A) of Nile Valley (Egypt) settlements [Kuper and 808 Kröpelin, 2006; Stanley et al., 2003; Weldeab et al., 2014].

810 Figure 6: Selected records of Heinrich Stadials (HS) 1 and 2. a) The reflectance (L*) record 811 of Arabian Sea core SO130-289KL [Deplazes et al., 2014]. b) TEX 86 SST estimates for 812 GeoB7702-3 [Castañeda et al., 2010]. c) Ice volume corrected $\delta \mathrm{D}_{\text {wax }}$ values from 813 GeoB7702-3. d) Iron (Fe) to potassium (K) ratios from core GeoB 9508-5 near the Senegal 814 River in West Africa [Mulitza et al., 2008]. The gray shading highlights HS 1 and 2. The 815 solid and dashed lines indicate the initiation and termination of HS1 in the GeoB7702-3 816 SST and $\delta \mathrm{D}_{\text {wax }}$ records, respectively. Note the ca. 1,300 year offset between HS1 as 817 recorded in the $\delta \mathrm{D}_{\text {wax }}$ and SST records. 

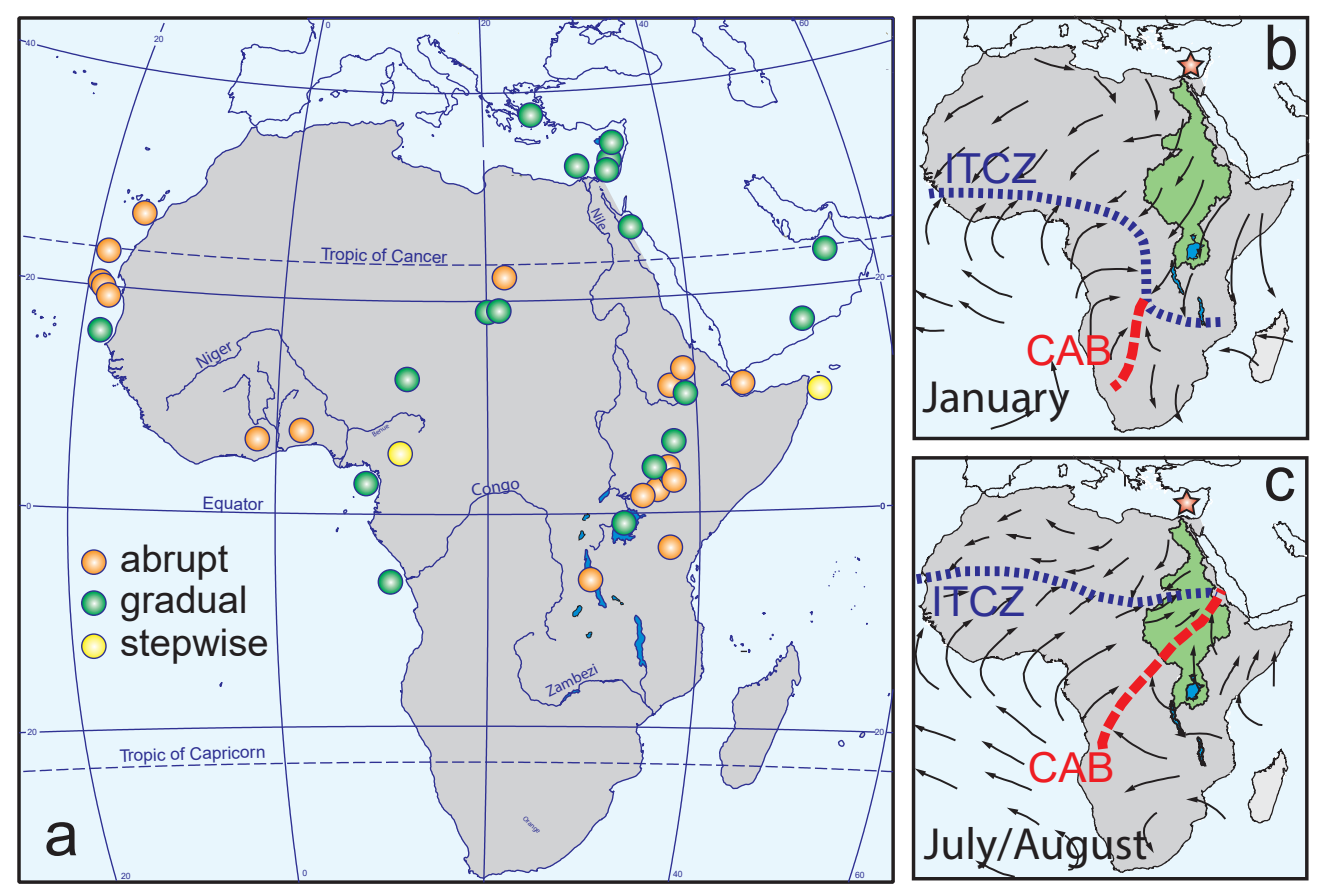

Figure 1 

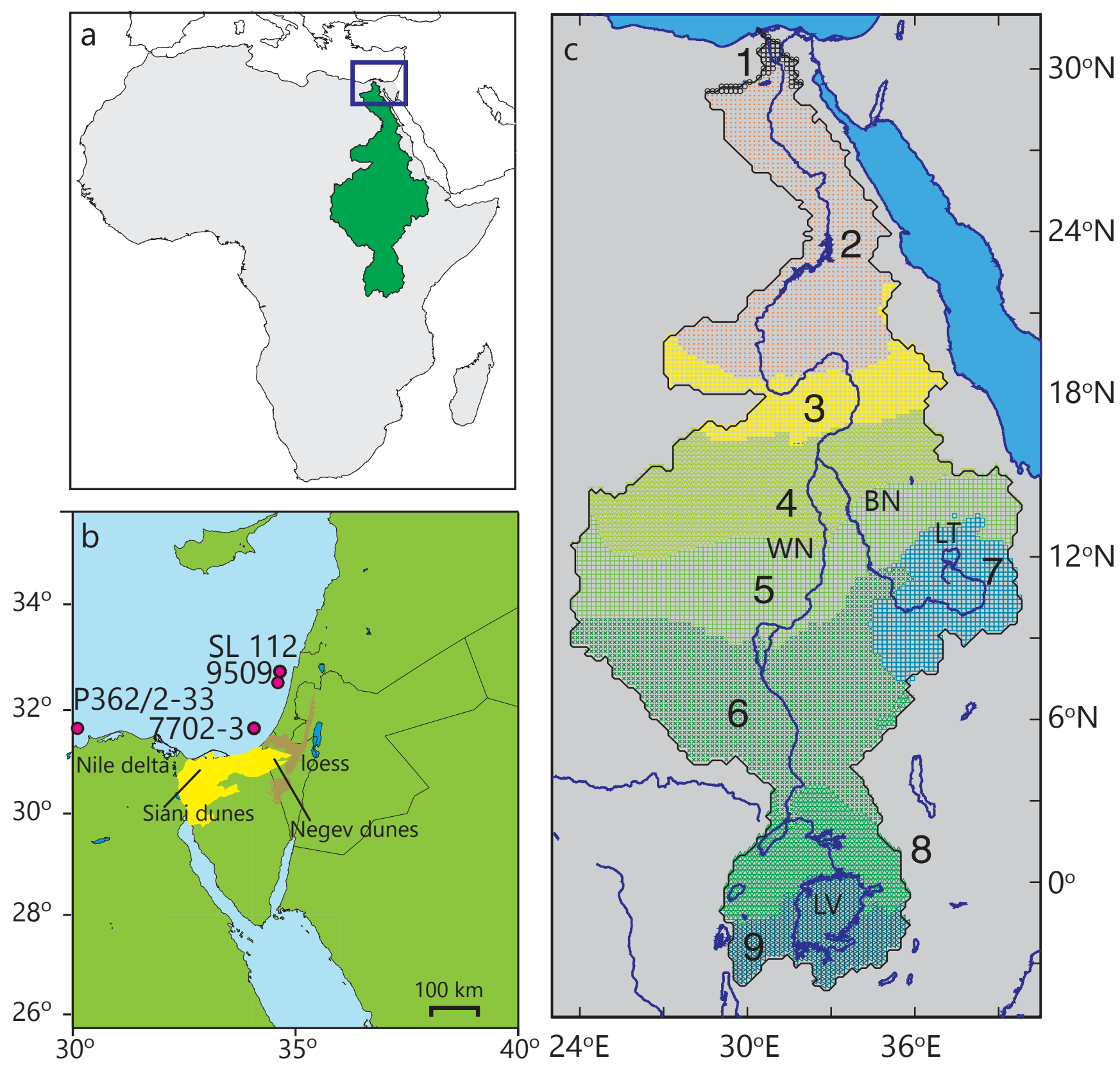

Figure 2 


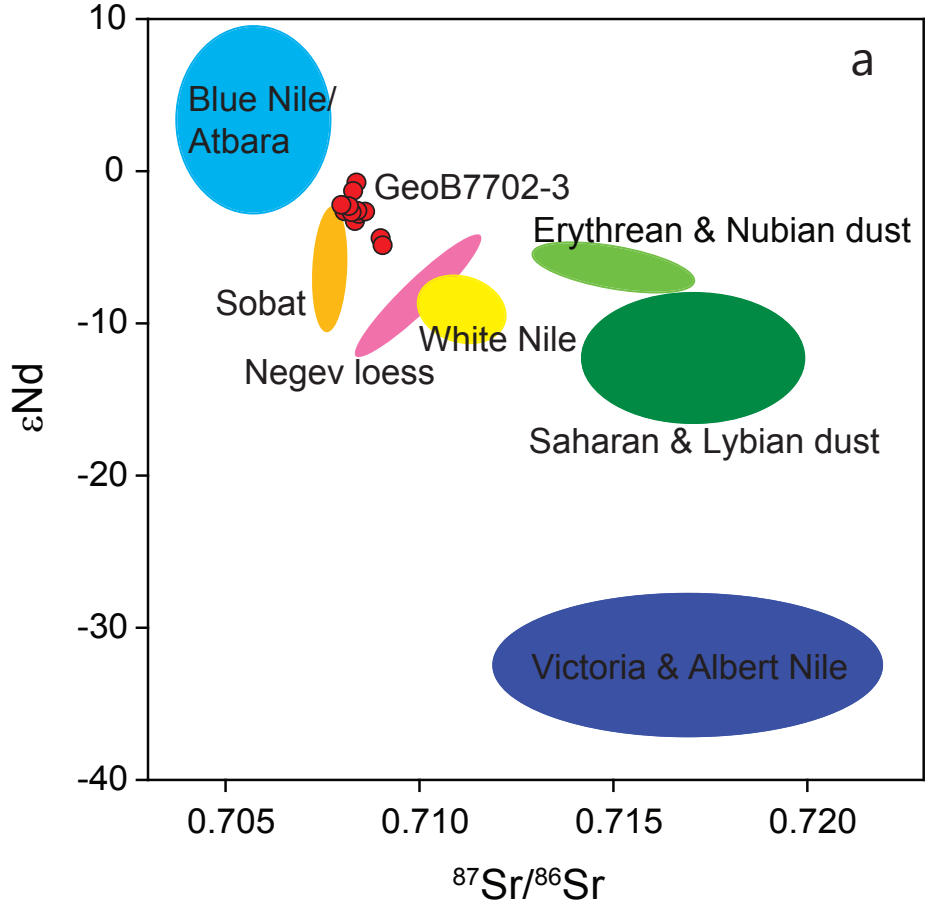

Figure 3

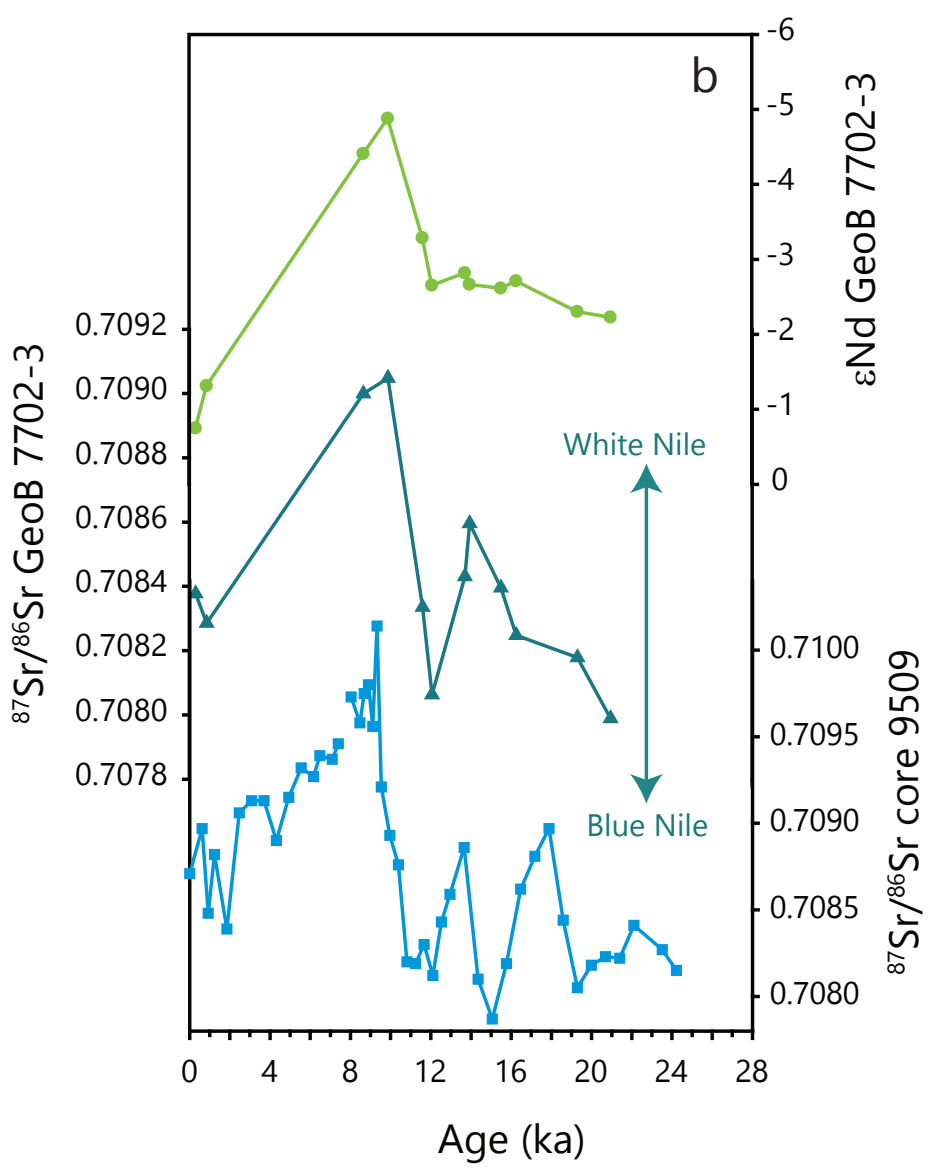




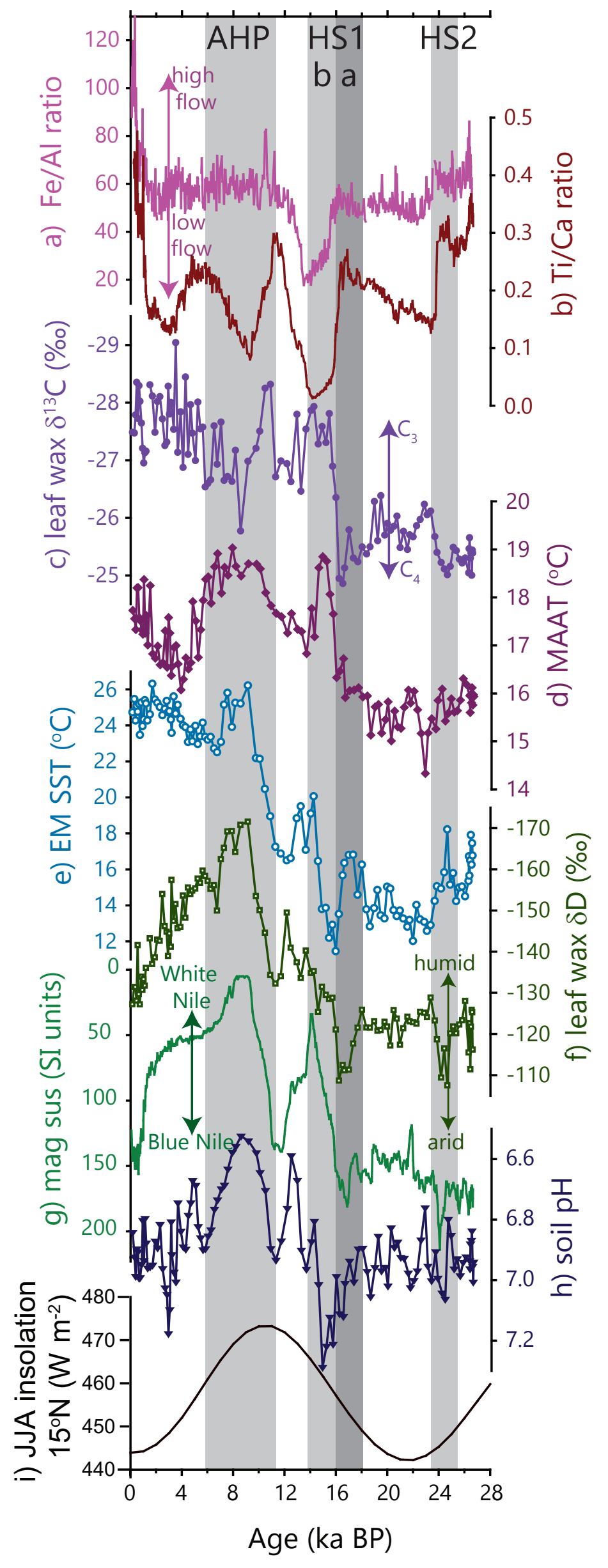

Figure 4 


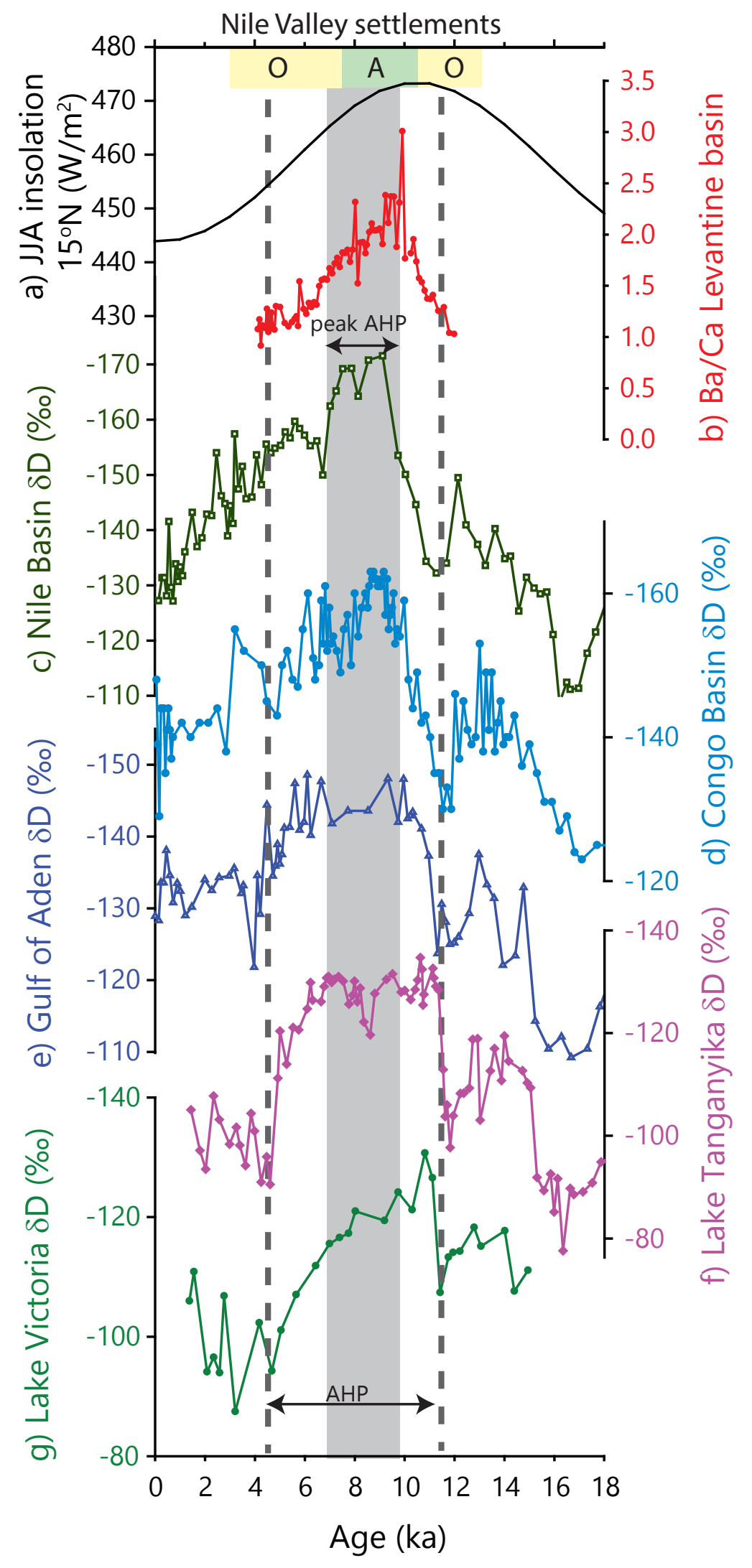

Figure 5 


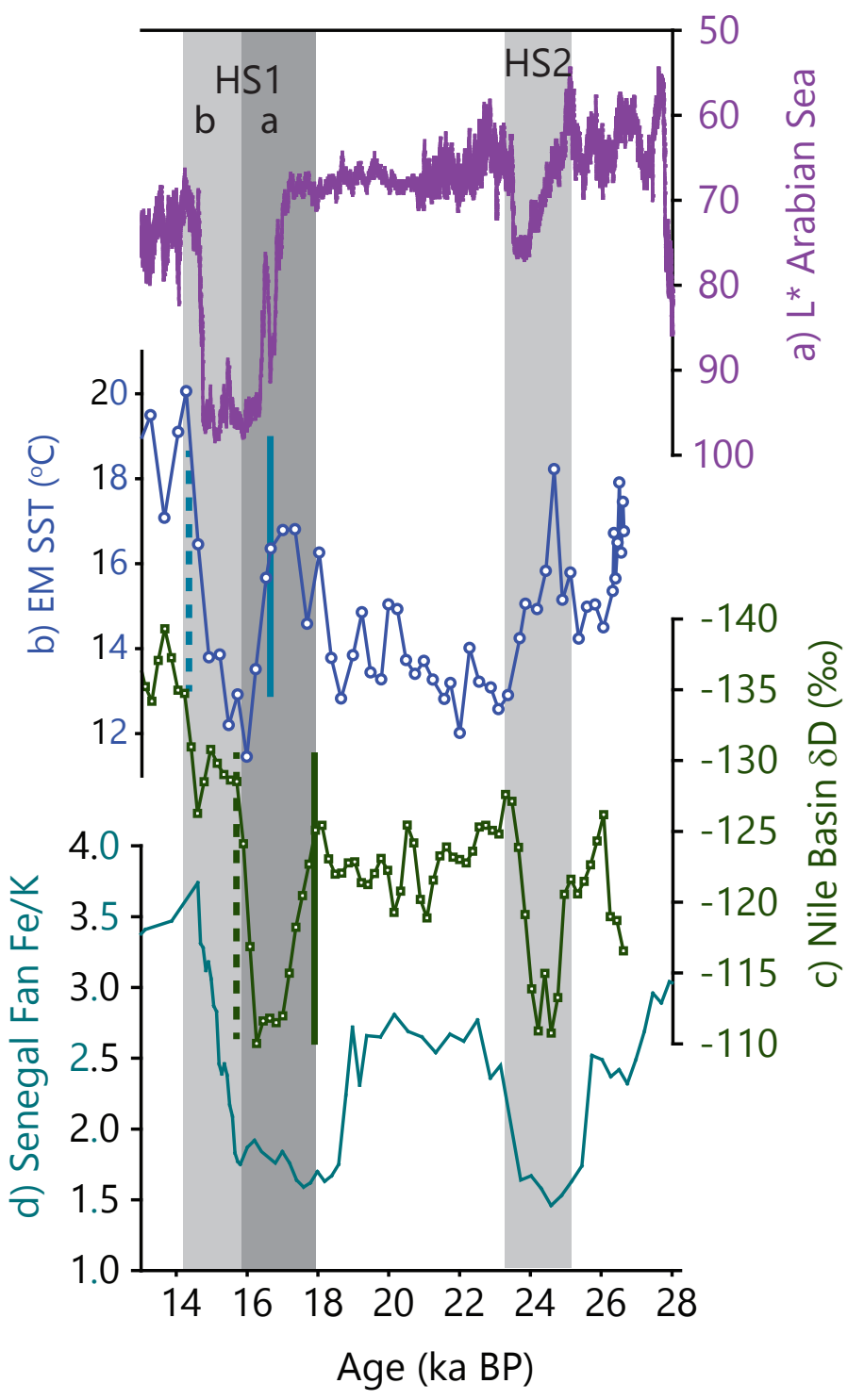

Figure 6 


\section{Supplementary Information: Hydroclimate variability in the Nile River Basin during the past 28,000 years}

\section{Figure 1 with full list of sites and references}

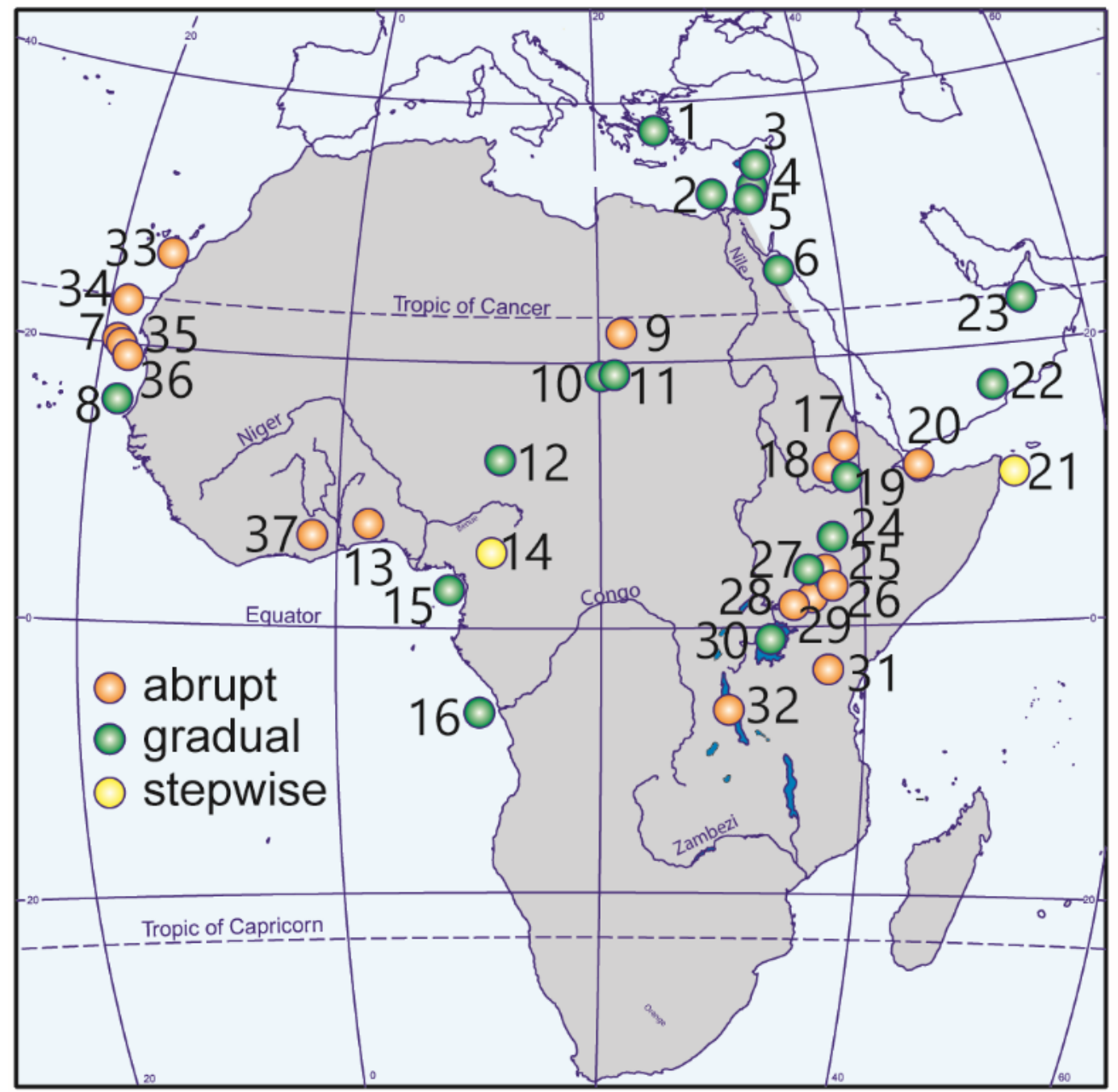

Figure 1 caption: In this version, the full site names and reference details are provided. The termination of the early Holocene Humid Period in North Africa. The colored circles indicate sites where the transition out of the African Humid Period is observed to be abrupt (orange), gradual (green) or stepwise (yellow). Note that the study locations depicted by the dots are approximate and in some cases have been shifted slightly where dots overlapped. The sites are as follows: 1. Agean Sea core SL143 [Ehrmann et al., 2013]. 2. Nile deep-sea fan core P362/2-33 [Blanchet et al., 2013]. 3. Eastern Mediterranean Sea core MD 9501 [Box et al., 2011]. 4. Eastern Mediterranean Sea Core 
SL112 [Weldeab et al., 2014]. 5. Eastern Mediterranean Sea core 9509 [Box et al., 2011]. 6. Red Sea core GeoB 5844-2 [Arz et al., 2003]. 7. ODP Site 658C off Cap Blanc, Mauritania [deMenocal et al., 2000]. 8. Core GeoB 9508-5, located near the mouth of the Senegal River. Note that two studies have been conducted on this core [Mulitza et al., 2008; Niedermeyer et al., 2010]. 9. The Gilf Kebir Plateau in southwest Egypt [Linstädter and Kröpelin, 2004]. 10. Lake Yoa in the Sahara [Kröpelin et al., 2008]. 11. Lake Yoa in the Sahara [Francus et al., 2013]. 12. Lake Chad core LT1 [Amaral et al., 2013]. 13. Lac Sele in Southern Benin [Salzmann and Hoelzmann, 2005]. 14. Core M4 from Lake Mbalang in central Cameroon [Vincens et al., 2010]. 15. Core MD03-2707 from the Gulf of Guinea [Weldeab et al., 2007]. 16. Core GeoB 6518 from the vicinity of the Congo River outflow. Note that two studies have been conducted on this core [Weijers et al., 2007; Schefuß et al., 2005]. 17. Core 03AL3/2 from Lake Ashenge in Northern Ethiopia [Marshall et al., 2009]. 18. Lake Tana core 03TL2 [Marshall et al., 2011]. 19. Lake Tana core 03TL2 [Costa et al., 2014]. 20. Gulf of Aden core P178-15P [Tierney et al., 2013]. 21. Core 905 from the Arabian Sea, offshore Somalia [Jung et al., 2004]. 22. Stalagmite Q5 from Qunf Cave in southern Oman [Fleitmann et al., 2003]. 23. Stalagmites H5 and H12 from Hoti Cave in northern Oman [Fleitmann et al., 2007]. 24. Core CB-01-09 from the Chew Bahir Basin in East African Rift Valley [Foerster et al., 2012]. 25. The Mt. Porr strand plain along the southeastern shore of Lake Turkana [Forman et al., 2014]. 26. Abandoned Holocene shorelines from the Lake Turkana basin, northern Kenya Rift [Garcin et al., 2012]. 27. Cores LT84-2P and LT84-7P from the southern and northern basin of Lake Turkana [Berke et al., 2012a]. 28. Suguta Valley lacustrine deposits [Junginger et al., 2014]. 29. Lake Suguta, northern Kenya Rift [Garcin et al., 2009]. 30. Lake Victoria core V95-1P [Berke et al., 2012b]. 31. Lake Challa, located on the east slope of Mt. Kilimanjaro, Kenya [Tierney et al., 2011]. 32. Lake Tanganyika cores NP04-KH04-3A-1K and NP04-KH04-4A-1K [Tierney et al., 2008]. 33-36. Northwest African margin cores OC437-7GC37 (33), OC437-7GC49 (34), OC437-7GC66 (35) and OC437-7GC68 (36) [McGee et al., 2013]. 37. Lake Bosumtwi ICDP drill core [Shanahan et al., 2015].

\section{Influence of vegetation change on leaf wax deuterium isotopes}

Following the approach of Kuechler et al. [2013], we use the $\delta^{13} \mathrm{C}_{\text {wax }}$ values to estimate the percent $\mathrm{C}_{4}$ vegetation shifts at site GeoB7702-3 along with published apparent fractionation factors of $123 \%$ for $\mathrm{C}_{3}$ vegetation and $-139 \%$ for $\mathrm{C}_{4}$ vegetation [Sachse et al., 2012]. We find that the maximum shift in $\delta \mathrm{D}_{\text {wax }}$ caused by vegetation changes is approximately $2 \%$ for the older portion of the record (Figure 2). Even considering the entire $\delta^{13} \mathrm{C}_{w a x}$ range of 4.1\%o in GeoB7702-3, the resulting shift in $\delta \mathrm{D}_{\text {wax }}$ of approximately $7 \%$ is minor in comparison to the large changes noted in 
the $\delta \mathrm{D}_{\text {wax }}$ record. Furthermore, the entire 0-28 ka BP Nile Basin $\delta \mathrm{D}_{\text {wax }}$ record displays similar trends to $\delta \mathrm{D}_{\text {wax }}$ records from the Congo Basin [Schefuß et al., 2005], the Gulf of Aden [Tierney et al., 2013] and Lake Tanganyika [Tierney et al., 2008] (Fig. 5), sites located vast distances apart and characterized by different vegetation types [White, 1983], further confirming that vegetation shifts were not a main factor driving variability in $\delta \mathrm{D}_{\operatorname{wax}}$. Indeed, a recent study of $\delta^{13} \mathrm{C}_{\text {wax }}$ and $\delta \mathrm{D}_{\text {wax }}$ in a transect of cores collected off the coast of western Africa concluded that vegetation changes $\left(\mathrm{C}_{3}\right.$ trees and $\mathrm{C}_{4}$ grasses) exert only a minor influence on $\delta \mathrm{D}_{\text {wax }}$ in comparison to changes in the isotopic composition of precipitation [Collins et al., 2013].

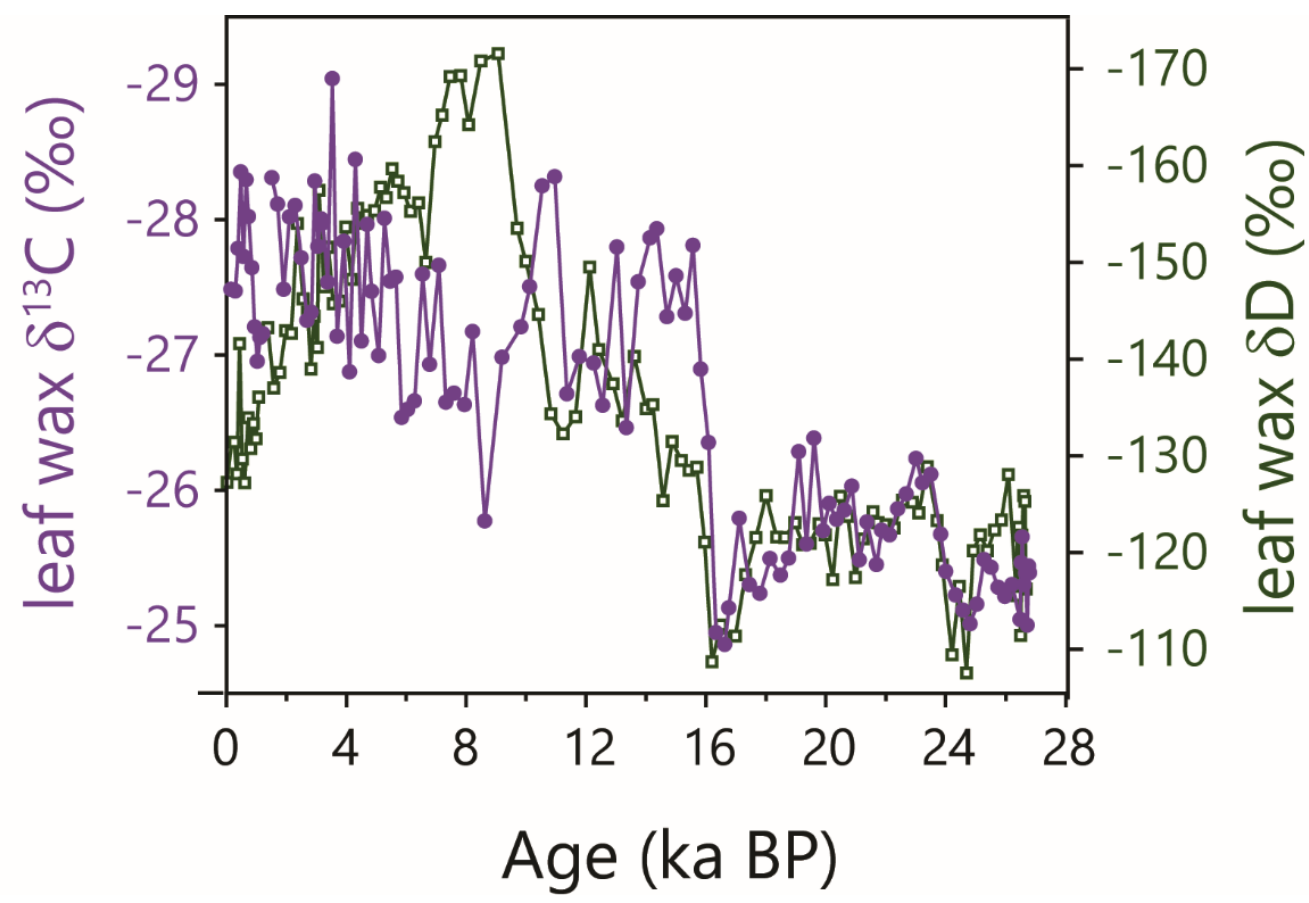

Figure 2 caption: Leaf wax $\delta^{13} \mathrm{C}$ (purple circles) and $\delta \mathrm{D}$ (open green squares) values for core GeoB7702-3 plotted on top of each other for comparison. 


\section{Supplemental References:}

Amaral, P., A. Vincens, J. Guiot, G. Buchet, P. Deschamps, J. Doumnang, and F. Sylvestre (2013), Palynological evidence for gradual vegetation and climate changes during the African Humid Period termination at $13^{\circ} \mathrm{N}$ from a Mega-Lake Chad sedimentary sequence, Climate of the Past, 9(1), 223-241.

Arz, H. W., J. P"atzold, P. J. Mu“ller, and M. O. Moammar (2003), Influence of Northern Hemisphere climate and global sea level rise on the restricted Red Sea marine environment during termination I, Paleoceanography, 18(2).

Berke, M. A., T. C. Johnson, J. P. Werne, S. Schouten, and J. S. Sinninghe Damsté (2012a), A mid-Holocene thermal maximum at the end of the African Humid Period, Earth and Planetary Science Letters, 351352(0), 95 - 104, doi:http://dx.doi.org/10.1016/j.epsl.2012.07.008.

Berke, M. A., T. C. Johnson, J. P. Werne, K. Grice, S. Schouten, and J. S. Sinninghe Damsté (2012b), Molecular records of climate variability and vegetation response since the Late Pleistocene in the Lake Victoria basin, East Africa, Quaternary Science Reviews, 55, 59-74.

Blanchet, C. L., R. Tjallingii, M. Frank, J. Lorenzen, A. Reitz, K. Brown, T. Feseker, and W. Bru“ckmann (2013), High-and low-latitude forcing of the Nile River regime during the Holocene inferred from laminated sediments of the Nile deep-sea fan, Earth and Planetary Science Letters, 364, 98-110.

Box, M., M. Krom, R. Cliff, M. Bar-Matthews, A. Almogi-Labin, A. Ayalon, and M. Paterne (2011), Response of the Nile and its catchment to millennial-scale climatic change since the LGM from $\mathrm{Sr}$ isotopes and major elements of East Mediterranean sediments, Quaternary Science Reviews, 30(3), 431-442.

Collins, J. A., E. Schefuß, S. Mulitza, M. Prange, M. Werner, T. Tharammal, A. Paul, and G. Wefer (2013), Estimating the hydrogen isotopic composition of past precipitation using leafwaxes from western Africa, Quaternary Science Reviews, 65, 88-101.

Costa, K., J. Russell, B. Konecky, and H. Lamb (2014), Isotopic reconstruction of the African Humid Period and Congo Air Boundary migration at Lake Tana, Ethiopia, Quaternary Science Reviews, 83(0), 58 - 67, doi:http://dx.doi.org/10.1016/j.quascirev.2013.10.031.

deMenocal, P., J. Ortiz, T. Guilderson, J. Adkins, M. Sarnthein, L. Baker, and M. Yarusinsky (2000), Abrupt onset and termination of the African Humid Period:: rapid climate responses to gradual insolation forcing, Quaternary Science Reviews, 19(15), 347 - 361, doi:http://dx.doi.org/ 10.1016/S0277-3791(99)00081-5.

Ehrmann, W., M. Seidel, and G. Schmiedl (2013), Dynamics of Late Quaternary North African humid periods documented in the clay mineral record of central Aegean Sea sediments, Global and Planetary Change, 107(0), 186 - 195, doi:http://dx.doi.org/10.1016/j.gloplacha.2013.05. 010.

Fleitmann, D., S. J. Burns, M. Mudelsee, U. Neff, J. Kramers, A. Mangini, and A. Matter (2003), Holocene forcing of the Indian monsoon recorded in a stalagmite from southern Oman, Science, 300(5626), 1737-1739.

Fleitmann, D., S. J. Burns, A. Mangini, M. Mudelsee, J. Kramers, I. Villa, U. Neff, A. A. AlSubbary, A. Buettner, D. Hippler, et al. (2007), Holocene ITCZ and Indian monsoon dynamics recorded in stalagmites from Oman and Yemen (Socotra), Quaternary Science Reviews, 26(1), $170-188$.

Foerster, V., A. Junginger, O. Langkamp, T. Gebru, A. Asrat, M. Umer, H. F. Lamb, V. Wennrich, J. Rethemeyer, N. Nowaczyk, et al. (2012), Climatic change recorded in the sediments of the Chew Bahir basin, southern Ethiopia, during the last 45,000 years, Quaternary International, 274, 25-37.

Forman, S. L., D. K. Wright, and C. Bloszies (2014), Variations in water level for Lake Turkana in the past 8500 years near Mt. Porr, Kenya and the transition from the African Humid Period to Holocene aridity, Quaternary Science Reviews, 97, 84-101. 
Francus, P., H. Von Suchodoletz, M. Dietze, R. V. Donner, F. Bouchard, A.-J. Roy, M. Fagot, D. Verschuren, and S. Kröpelin (2013), Varved sediments of Lake Yoa (Ounianga Kebir, Chad) reveal progressive drying of the Sahara during the last 6100 years, Sedimentology, 60(4), 911-934.

Garcin, Y., A. Junginger, D. Melnick, D. O. Olago, M. R. Strecker, and

M. H. Trauth (2009), Late Pleistocene-Holocene rise and collapse of Lake Suguta, northern

Kenya Rift, Quaternary Science Reviews, 28(9), 911-925.

Garcin, Y., D. Melnick, M. R. Strecker, D. Olago, and J.-J. Tiercelin (2012), East African midHolocene wetdry transition recorded in palaeoshorelines of Lake Turkana, northern Kenya Rift, Earth and Planetary Science Letters, 331332(0), 322 - 334, doi:http://dx.doi.org/10.1016/j. eps1.2012.03.016.

Jung, S., G. Davies, G. Ganssen, and D. Kroon (2004), Stepwise Holocene aridification in NE Africa deduced from dust-borne radiogenic isotope records, Earth and Planetary Science Letters, 221(1), 27-37.

Junginger, A., S. Roller, L. A. Olaka, and M. H. Trauth (2014), The effects of solar irradiation changes on the migration of the Congo Air Boundary and water levels of paleo-Lake Suguta, Northern Kenya Rift, during the African Humid Period (15-5 ka BP), Palaeogeography, Palaeoclimatology, Palaeoecology, 396(0), 1 - 16, doi:http://dx.doi.org/10.1016/j. palaeo.2013.12.007.

Kröpelin, S., D. Verschuren, A.-M. L'ezine, H. Eggermont, C. Cocquyt, P. Francus, J.-P. Cazet, M. Fagot, B. Rumes, J. Russell, et al. (2008), Climate-driven ecosystem succession in the Sahara: the past 6000 years, Science, 320(5877), 765-768.

Kuechler, R., E. Schefuß, B. Beckmann, L. Dupont, and G. Wefer (2013), Nw African hydrology and vegetation during the Last Glacial cycle reflected in plant-wax-specific hydrogen and carbon isotopes, Quaternary Science Reviews, 82, 56-67.

Linstädter, J., and S. Kröpelin (2004), Wadi Bakht revisited: Holocene climate change and prehistoric occupation in the Gilf Kebir region of the Eastern Sahara, SW Egypt, Geoarchaeology, 19(8), 753-778.

McGee, D., P. deMenocal, G. Winckler, J. Stuut, and L. Bradtmiller (2013), The magnitude, timing and abruptness of changes in North African dust deposition over the last 20,000 yr, Earth and Planetary Science Letters, 371, 163-176.

Marshall, M. H., H. F. Lamb, S. J. Davies, M. J. Leng, Z. Kubsa, M. Umer, and C. Bryant (2009), Climatic change in northern Ethiopia during the past 17,000 years: a diatom and stable isotope record from Lake Ashenge, Palaeogeography, Palaeoclimatology, Palaeoecology, 279(1), 114-127.

Marshall, M. H., H. F. Lamb, D. Huws, S. J. Davies, R. Bates, J. Bloemendal, J. Boyle, M. J. Leng, M. Umer, and C. Bryant (2011), Late Pleistocene and Holocene drought events at Lake Tana, the source of the Blue Nile, Global and Planetary Change, 78(3), 147-161.

Mulitza, S., M. Prange, J.-B. Stuut, M. Zabel, T. von Dobeneck, A. C. Itambi, J. Nizou, M. Schulz, and G. Wefer (2008), Sahel megadroughts triggered by glacial slowdowns of Atlantic meridional overturning, Paleoceanography, 23(4).

Nicholson, S. E. (2011), Dryland climatology, Cambridge University Press.

Niedermeyer, E. M., E. Schefuß, A. L. Sessions, S. Mulitza, G. Mollenhauer, M. Schulz, and G. Wefer (2010), Orbital-and millennial-scale changes in the hydrologic cycle and vegetation in the western African sahel: insights from individual plant wax $\delta \mathrm{D}_{\text {wax }}$ and $\delta^{13} \mathrm{C}_{\text {wax }}$, Quaternary Science Reviews, 29(23), 2996-3005.

Sachse, D., I. Billault, G. J. Bowen, Y. Chikaraishi, T. E. Dawson, S. J. Feakins, K. H. Freeman, C. R. Magill, F. A. McInerney, M. T. Van der Meer, et al. (2012), Molecular paleohydrology: interpreting the hydrogen-isotopic composition of lipid biomarkers from photosynthesizing organisms, Annu. Rev. Earth Planet. Sci, 40, 221-249. 
Salzmann, U., and P. Hoelzmann (2005), The Dahomey Gap: an abrupt climatically induced rain forest fragmentation in West Africa during the late Holocene, The Holocene, 15(2), 190-199.

Schefuß, E., S. Schouten, and R. R. Schneider (2005), Climatic controls on central African hydrology during the past 20,000 years, Nature, 437(7061), 1003-1006.

Tierney, J. E., J. M. Russell, Y. Huang, J. S. Sinninghe Damsté, E. C. Hopmans, and A. S. Cohen (2008), Northern hemisphere controls on tropical southeast African climate during the past 60,000 years, Science, 322(5899), 252-255.

Tierney, J. E., J. M. Russell, J. S. Sinninghe Damsté, Y. Huang, and D. Verschuren (2011), Late Quaternary behavior of the East African monsoon and the importance of the Congo Air Boundary, Quaternary Science Reviews, 30(78), 798 - 807, doi:http://dx.doi.org/10.1016/j.quascirev. 2011.01.017.

Tierney, J. E., et al. (2013), Abrupt shifts in Horn of Africa hydroclimate since the Last Glacial Maximum, Science, 342(6160), 843-846.

Vincens, A., G. Buchet, M. Servant, et al. (2010), Vegetation response to the "African Humid Period" termination in Central Cameroon $\left(7^{\circ} \mathrm{N}\right)$ - new pollen insight from Lake Mbalang, Climate of the Past, 6(3), 281-294.

Weijers, J. W., E. Schefuß, S. Schouten, and J. S. Sinninghe Damsté (2007), Coupled thermal and hydrological evolution of tropical Africa over the last deglaciation, Science, 315(5819), 1701-1704.

Weldeab, S., D. W. Lea, R. R. Schneider, and N. Andersen (2007), Centennial scale climate instabilities in a wet early Holocene West African monsoon, Geophysical Research Letters, 34(24).

Weldeab, S., V. Menke, and G. Schmiedl (2014), The pace of East African monsoon evolution during the Holocene, Geophysical Research Letters, 41(5), 1724-1732.

White, F. (1983), The vegetation of Africa. A descriptive memoir to accompany the Unesco/AETFAT/UNSO vegetation map of Africa, Natural Resources Research 20, 356 pp., UNESCO, Paris. 